\title{
Hydraulic Fracturing, Cumulative Development and Earthquakes in the Peace River Region of British Columbia, Canada
}

\author{
Allan R. Chapman \\ Chapman Geoscience Ltd., Victoria, British Columbia, Canada \\ Email: chapman.geoscience @gmail.com
}

How to cite this paper: Chapman, A. R. (2021). Hydraulic Fracturing, Cumulative Development and Earthquakes in the Peace River Region of British Columbia, Canada. Journal of Geoscience and Environment Protection, 9, 55-82.

https://doi.org/10.4236/gep.2021.95006

Received: April 15, 2021

Accepted: May 23, 2021

Published: May 26, 2021

Copyright $\odot 2021$ by author(s) and Scientific Research Publishing Inc. This work is licensed under the Creative Commons Attribution International License (CC BY 4.0)

http://creativecommons.org/licenses/by/4.0/

\begin{abstract}
Unconventional petroleum development involving large volume fluid injection into horizontal well bores, referred to as hydraulic fracturing (HF, or fracking), began in the Montney Trend of northeast British Columbia, Canada, in 2005, quickly initiating earthquakes. Earthquake frequency increased substantially in the Montney by 2008 , in relation to the number of wells fracked and the volume of injected frack water. A spatiotemporal filter was used to associate earthquakes with HF wells. A total of 439 earthquakes (M 1.0 - 4.6 (NRCAN catalogue) during 2013-2019 have close association with HF activity, of which $77 \%$ are associated with three operators. Fifteen percent of HF wells in the Montney are associated with these earthquakes, while $1.7 \%$ of HF wells are associated with $\mathbf{M} \geq 3.0$ earthquakes. There are strong linear relationships between the maximum earthquake magnitude each year and the annual volume of injected frack fluid. $\mathbf{M} \geq 3.0$ earthquakes are associated with large cumulative frack water volumes for antecedent time periods of 1 3 years, often with fluid injection by multiple operators. Eighty-seven percent of the Montney $\mathbf{M} \geq 3.0$ earthquakes have associated HF triggering events, but a few are sufficiently distant to be ambiguous. Distances from the induced earthquake epicentres indicate a variety of causal mechanisms are involved. It is concluded that $\sim 60 \%$ - $70 \%$ of $\mathrm{M} \geq 3.0$ earthquakes are induced by hydraulic fracturing. HF-induced earthquakes can be considered in part related to the cumulative development density from multiple proximal operators and cumulative antecedent fluid injection over periods ranging from a few months to a few years. It is probable that induced earthquakes of $\mathbf{M}>5$ will occur in the future. There are significant public safety and infrastructure risks associated with future HF-induced earthquakes in the Peace River area. To carry out HF operations effectively and safely, potentially destructive earthquakes must be avoided or mitigated. The Traffic Light Protocol mitigation
\end{abstract}


system used in British Columbia appears unlikely to prevent large magnitude earthquakes. Risk avoidance therefore becomes important and could include the establishment of frack-free zones proximal to populations and critical infrastructure.

\section{Keywords}

Hydraulic Fracturing, Induced Earthquakes, Montney Trend

\section{Introduction}

Earthquakes associated with petroleum production in northeastern British Columbia (NEBC), referred to as induced seismicity, have been recognized for many decades, beginning with large-volume fluid injections into oil reservoirs to enhance conventional oil recovery (Horner et al., 1994), and fluid injection into oil and gas wastewater disposal wells (Schultz et al., 2014; Weingarten et al., 2015; BCOGC, 2014). More recently, earthquake activity initiated by hydraulic fracturing has emerged as a significant concern in the Peace River region of NEBC, triggering focused research (Atkinson et al., 2020; Schultz et al., 2018; Barbaie Mahani et al., 2017; Atkinson et al., 2016; Bao \& Eaton, 2016; others). Hydraulic fracturing (also referred to as HF, or the colloquial "fracking" in this paper) is a well stimulation technique that is a key element of unconventional petroleum development (also referred to as shale gas, tight gas, shale oil, etc.), where high volume water-based fluid injection along horizontal well bores is used to fracture the petroleum-bearing rock, creating permeability and enhancing petroleum recovery.

This paper examines relationships between hydraulic fracturing and earthquakes in the Peace River region of NEBC. Numerous "felt" earthquakes have occurred in Peace region over the past 10+ years, notably including three large events in a 48-minute period on 29 November 2018, with moment magnitudes $\left(\mathbf{M}_{\mathrm{w}}\right)$ of 4.6, 4.0 and 3.4, triggering temporary work shutdown at the BC Hydro Site C dam construction site located $23 \mathrm{~km}$ to the north (Nikiforuk, 2018), and, as well, a $\mathbf{M}_{\mathrm{w}} 4.6$ earthquake on 17 August 2015 at a remote location $20 \mathrm{~km}$ east of the community of Pink Mountain. The significance of the public safety and infrastructure risks associated with HF-related earthquakes in the Peace River region cannot be overstated. This paper examines the frequency and magnitude of induced earthquakes in relation to HF injection fluid volumes over varying antecedent time periods; it quantifies differences amongst petroleum operators in relation to induced earthquakes; and it evaluates the mitigation approaches, including regulatory requirements, intended to reduce potential public safety, infrastructure and environmental risks. It suggests what the earthquake future for the Peace Region might be. Investigation of induced earthquakes associated with the operation of water disposal wells is not included. 


\section{Study Area}

This study focuses on the Montney Play Trend (referred to in this paper as the Montney). Following developments in the Barnett Shale in Texas in the late 1990s, the industry transformation in BC to unconventional petroleum began with the 2003-2010 gold rush of petroleum tenure sales of $\$ 7.5$ billion for 4.7 million hectares of land across NEBC (BCGOV, 2020a). The first multistage HF in a NEBC horizontal well occurred near Dawson Creek in July 2005 (BCOGC 2012a). In the years' since, many thousands of wells have been drilled and fracked in four areas: the Horn River Basin, Liard basin, Cordova Embayment, and the Montney Trend. The BC Oil and Gas Commission (BCOGC), the regulator of oil and gas activity in $\mathrm{BC}$, reports that unconventional petroleum activity in the Horn River Basin, the Liard basin and Cordova Embayment was largely abandoned by 2016 (BCOGC, 2021), leaving just the Montney Trend with activity.

The Montney has an area of $\sim 26,600 \mathrm{~km}^{2}$, extending from south of the community of Dawson Creek to $\sim 200 \mathrm{~km}$ north-west of the community of Fort St John, and consisting of Triassic aged siltstones (Euzen et al., 2018; BCOGC 2012a). Most of the Montney is contained within the drainage of the Peace River, although the northern portions are within the Sikanni Chief River watershed, which drains northward to the Fort Nelson and Liard rivers.

The Montney has been divided by the BCOGC into two primary zones for the understanding of HF-induced earthquakes (Figure 1). These are the Kiskatinaw Seismic Monitoring and Mitigation Area (KSMMA) and the North Peace Ground Motion Monitoring Area (NPGMMA). The KSMMA comprises 9\% of the Montney and is centred on the Peace River, encompassing the communities of Dawson Creek, Fort St. John and Taylor. The BC Hydro Site C dam location is within the KSMMA. The NPGMMA comprises $26 \%$ of the Montney, extending from the north side of the Peace River near Hudson's Hope, skirting the west edge of the community of Upper Halfway (Halfway River First Nation), to north of Pink Mountain. The BC Hydro WAC Bennett and Peace Canyon dams are proximal to the south end of the NPGMMA. The remaining 65\% of the Montney is seismically unzoned. The KSMMA is predominantly private agricultural land with dispersed rural population and three sizable communities, whereas the NPGMMA is predominantly sparsely populated Crown land with a significant First Nation community.

Structural differences between the KSMMA and NPGMMA may account for seismogenic differences between the two areas. The KSMMA overlies the Dawson Creek Graben Complex, where faults have been reactivated due to ice compression and decompression during recent continental glaciation (Barclay et al., 1990), whereas the dominant seismogenicity of the NPGMMA results from movement along strike-slip faults associated with the Hay River Fault Zone, in the thrust-and-fold belt of the Rocky Mountain foothills (Thompson, 1989). 


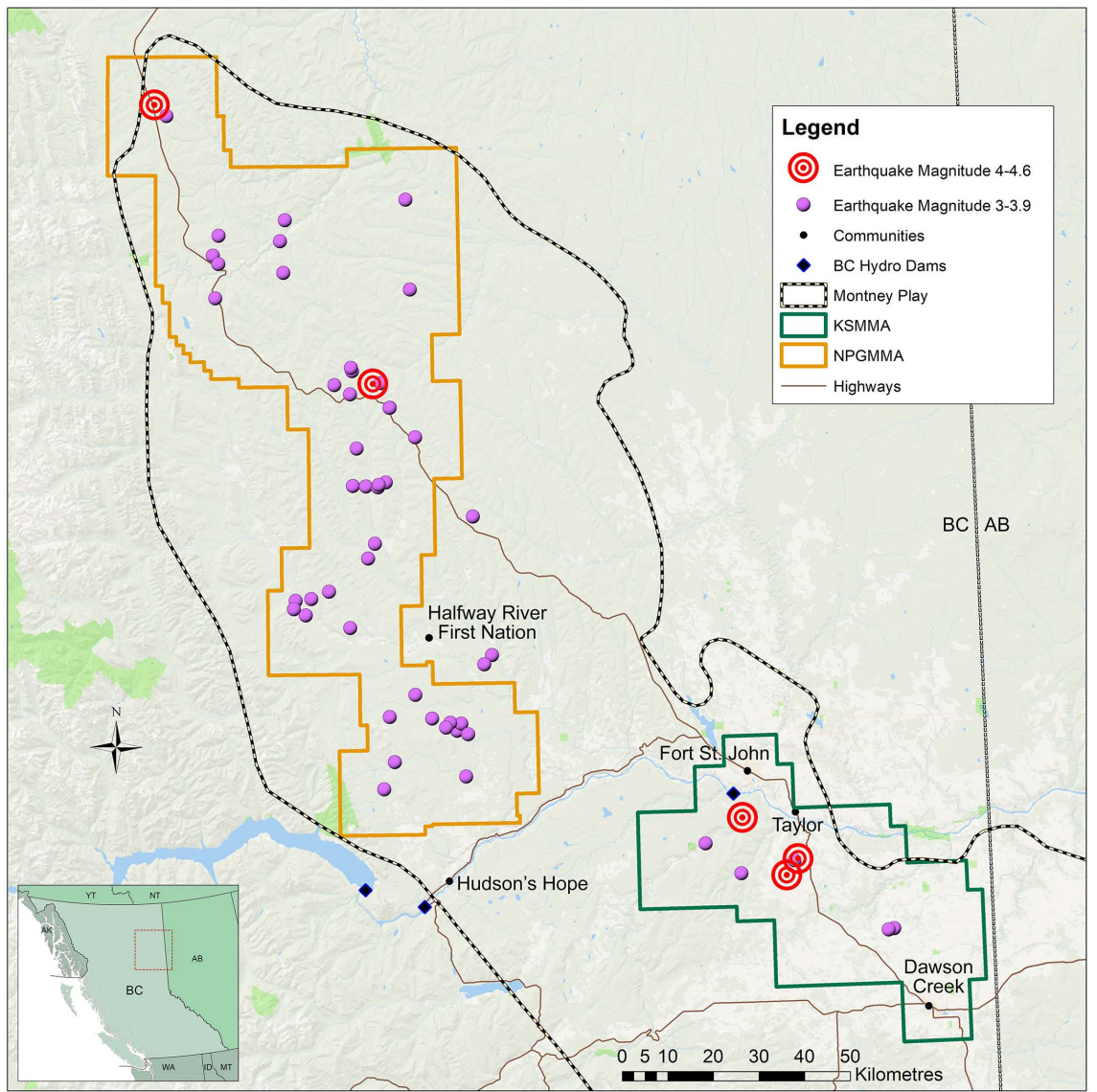

Figure 1. Location Map, showing the Montney Play Trend, the Kiskatinaw Seismic Monitoring and Mitigation Area (KSMMA), the North Peace Ground Motion Monitoring Area (NPGMMA) and magnitude 3+ and 4+ earthquakes (2013-2019). The location noted as Halfway River First Nation refers to the community of Upper Halfway.

\section{Data and Analysis}

The primary data used for this report are earthquake data compiled and published in the Canadian National Earthquake Database by Natural Resources Canada (NRCAN), and well completion data compiled and published by the BCOGC. The National Earthquake Database is based on the Canadian National Seismographic Network (CNSN) and is the de facto standard for earthquake monitoring and mapping in Canada (Visser et al., 2017). The network currently consists of 12 stations in NEBC, of which only two were operating before March 2013. Earthquake data for 2000-2019 were extracted from the National Earthquake Database (NRCAN, 2020). Because of the enhancement of the CNSN network in early 2013, the pre- and post-2013 seismic events are not directly comparable. Analysis of data for the 2000-2012 period was limited to only the "felt" events of $\mathbf{M} \geq 3$ 3.0. Earthquakes from the NEBC earthquake catalogues compiled by Visser et al. $(2017,2020)$ were extracted and used for portions of this report. These catalogues combine private industry and university seismographic data with the NRCAN data and report a significantly greater number of small magnitude earthquakes than the NRCAN catalogue. As well, they have 
enhanced earthquake epicentre locational accuracy. However, because the Visser et al. $(2017,2020)$ catalogues are limited to just 2014-2016 for all the Montney and to just the KSMMA portion of the Montney for 2017-2018, the primary analysis for this report is based on the NRCAN earthquake catalogue.

The well and HF data were compiled from the BCOGC's Frac Focus data set, for the 2012 to 2019 period (BCOGC, 2020a), a year prior to the period of enhanced NRCAN seismic data. The Frac Focus data were summarized to create one record per well, for all the petroleum wells fracked during the period. Other data extracted from the BCOGC's Open Data Portal (BCOGC, 2020b, 2020c) and from Geoscience BC (2020) were used in this analysis.

Wells and well pads were associated with earthquakes using a spatiotemporal association filter, using the QGIS geographic information system (QGIS, 2020). A 5-km radius buffer was assigned to each earthquake, consistent with the approach used by BCOGC (2012b) and others. The buffer radius is slightly larger than the $\sim 3 \mathrm{~km}$ length of horizontal bore associated with the unconventional petroleum wells (Lemko \& Foster, 2016). In addition, the buffer accommodates some of the accuracy uncertainty in earthquake location from the CNSN.

For each earthquake where there are wells located within the $5-\mathrm{km}$ radius buffer, associated HF water volumes for varying antecedent time periods were calculated: 30 days, 90 days, 1 year, 2 years, 3 years, and total antecedent. For this report, the antecedent period of 90 days is used to define an HF-associated earthquake, similar to Ghofrani and Atkinson (2020). This does not imply direct cause and effect between an individual well or well operator and the earthquake but is noted as an association. In addition, the frack water volume for the most probable HF event triggering an $\mathbf{M} \geq 3.0$ earthquake as determined for the well fracked immediately (up to 14 days) before the earthquake. Initially, the query for the triggering HF events was contained within the 5-km radius buffer. Upon review it was evident that many of the triggering HF events were more distant that $5-\mathrm{km}$ from the earthquake. There were clusters of earthquakes associated with fracking on a well pad, where some of the earthquakes in the cluster were well beyond 5-km from the triggering well. As well, comparison of the earthquake epicentres from the Visser et al. $(2017,2020)$ and NRCAN catalogues, for earthquakes contained in both catalogues, indicted spatial uncertainty in epicentre location of up to $10-\mathrm{km}$. As a result, a second query was done using a $15-\mathrm{km}$ buffer radius. Additionally, precursor earthquakes were determined for all the $\mathbf{M}$ $\geq 3.0$ earthquakes, determined as any earthquake of $\mathbf{M} \geq 2.0$ occurring within a $10-\mathrm{km}$ radius and up to 30 -days before the $M \geq 3.0$ event, using the NRCAN catalogue. Statistical analysis was completed using Systat v.13 (Systat, 2020).

\section{Analysis and Results}

\subsection{Wells, Well Pads, Water Use}

A total of 2865 wells in the Montney are reported as being hydraulically fractured during the 2012-2019 period (Figure 2). The five largest operators are 
Ovintiv (formerly Encana): 570 wells, Petronas (formerly Progress Energy): 552 wells, Tourmaline Oil: 413 wells, Shell: 255 wells and Painted Pony: 181 wells, together comprising almost $70 \%$ of the HF wells over the eight years. There are differences across the zones in the Montney. Despite being only $9 \%$ of the Montney area, $42 \%$ of the Montney HF wells are in the KSSMA, with Ovintiv having the greatest number of wells, followed by Tourmaline Oil, Shell, Crew Energy, ARC Resources and Canadian Natural Resources Ltd. (CNRL). These six operators are responsible for $99 \%$ of the HF wells in the KSSMA. Different companies dominate in the NPGMMA, containing 36\% of the Montney HF wells. Petronas alone accounts for 52\% of the NPGMMA HF wells and is followed somewhat distantly by Painted Pony, Tourmaline Oil, Pacific Canbriam and Saguaro. Outside these two seismically zoned areas a variety of companies operate in the remaining $65 \%$ of the Montney, led by Ovintiv, Shell, Murphy Oil, Storm Resources and ConocoPhillips. The peak in HF, to date, in the NPGMMA was 2014-2015, while the peak in the KSMMA was later, in 2018.

Trends over time in HF activity across the Montney are related to economic factors, with industry attention moving away from methane or natural gas and towards natural gas liquids (condensate). The NPGGA contains largely dry gas (i.e., just methane) whereas the KSMMA has abundant natural gas liquids (BCOGC 2012a). During 2016-2019 natural gas liquids averaged $\$ 6.38$ (USD per MMBtu) (Canada Energy Regulator, 2020) a substantial premium to the dry methane price of $\$ 2.40$ (USD per MMBtu), enhancing the development focus on the KSMMA area and away from the NPGMMA.

Over the 2012-2019 period, a total of 39 million $\mathrm{m}^{3}$ of water was used for fracking in the Montney. The volume of water used per well has increased steadily over the eight-year period, from an average of $7077 \mathrm{~m}^{3}$ per well in 2012 to 22,054 $\mathrm{m}^{3}$ per well in 2019 (Figure 3). ConocoPhillips stands out, using an average of $83,000 \mathrm{~m}^{3}$ per well for 13 wells in 2019. It is not known whether ConocoPhillips is an outlier or a harbinger, however, there appears to be a trend emerging amongst several Montney operators towards significantly larger water use per well. Ovintiv, Petronas, CNRL, ARC Resources, Pacific Canbriam and ConocoPhillips all had multiple HF wells in 2019 using 30,000+ $\mathrm{m}^{3}$ per well.

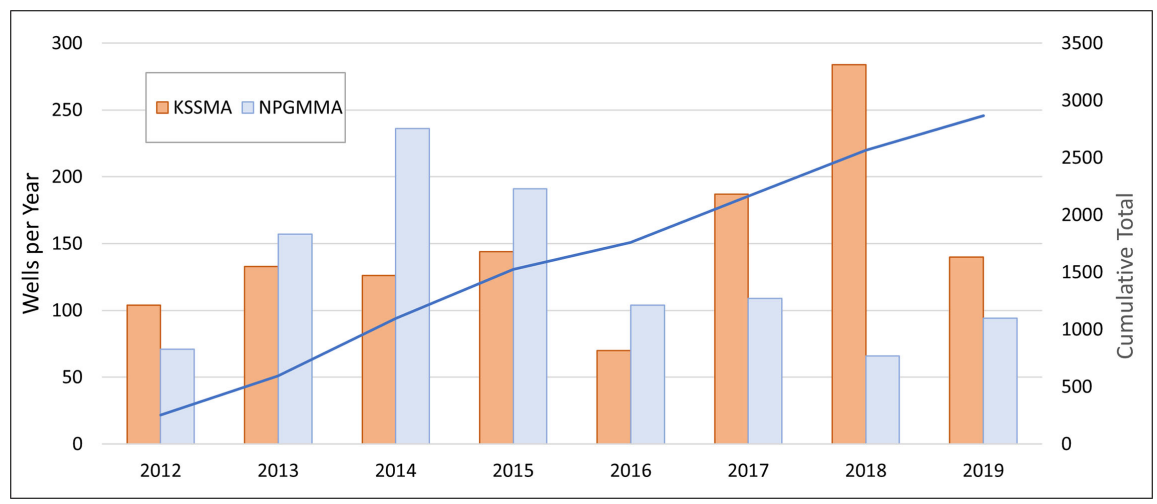

Figure 2. Number of hydraulically fractured wells in the Montney Play Trend, 2012-2019. 


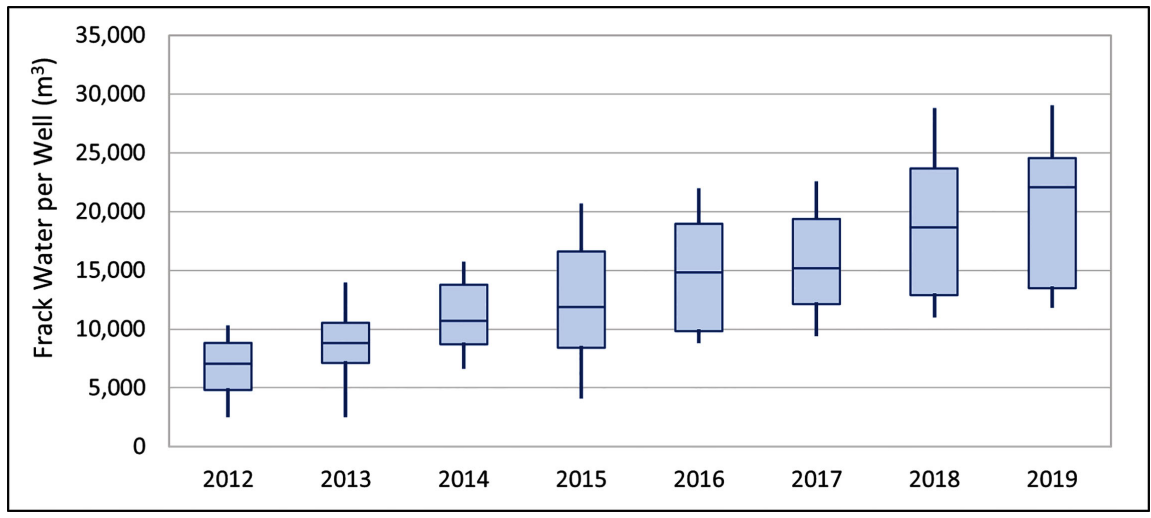

Figure 3. Water use for hydraulic fracturing in the Montney Play $\left(\mathrm{m}^{3}\right.$ per well).

The 2865 wells hydraulically fractured during 2012-2019 are situated on a total of 639 well pads, with a Montney average of 4.5 wells per pad, well below the $20+$ wells on each well pad anticipated at full development, as has been done on some pads in the KSMMA (Table 1). The small number of wells per pad suggests that most of the Montney operations to date have remained in the exploratory and appraisal phases of activity, with some exceptions. Only in the KSMMA are some operators approaching full development on some well pads. Ovintiv has one well pad with $29 \mathrm{HF}$ wells and has six pads with 20+ wells. In the NPGMMA, Petronas, the largest operator, has built-out extensive infrastructure across a large geographic area to appraise production potential, but has minimal activity to date at the individual well pads. Petronas has 146 well pads in the NPGMMA, averaging 3.7 HF wells per pad, with no more than 10 wells on any pad.

In cases of multiple wells on a single well pad, the water injection can be very large. ConocoPhillips injected nearly 1.1 million $\mathrm{m}^{3}$ of frack fluid from a single well pad, followed by Ovintiv with $550,000 \mathrm{~m}^{3}$ injected from one pad and five pads each with greater than $300,000 \mathrm{~m}^{3}$ total frack fluid injection.

\subsection{Earthquakes}

The Canadian National Earthquake Database contains 175 earthquakes for the 2000-2012 period (M 1.0 - 4.2) with epicentres in the Montney, of which 37 earthquakes were $\mathbf{M} \geq 3.0$, with a maximum magnitude of $\mathbf{M} 4$.2. For just the 2013-2019 period, following the enhancement of the seismic monitoring network, 975 earthquakes were recorded (M 1.0 - 4.6) across the Montney, 647 in the NPGMMA, 227 in the KSSMA and 101 across the remainder of the Montney. Fifty-six earthquakes (6\%) were $\mathbf{M} \geq 3.0$. Five earthquakes exceeded $\mathbf{M} 4.0$ (three in the KSMMA and two in the NPGMMA). Earthquakes with magnitudes $\geq 3.0$ are generally "felt" with ground shaking on the ground surface for some distance from the earthquake epicentre; at magnitudes $\geq 4.0$ the surface manifestation can be substantial, with damage to buildings and infrastructure (Atkinson et al., 2020; Lei et al., 2019). These $\mathbf{M} \geq 3.0$ earthquakes are a threshold mag- 
nitude for events of particular interest, as they are the drivers of public safety and infrastructure risk. As noted, the earthquake catalogues of Visser et al. (2017, 2020) contain a substantially larger number of small earthquakes (generally less than $\mathbf{M}$ 2).

Table 1. Summary of hydraulically fractured wells, well pads, hydraulic fracturing water use, associated earthquakes and land tenure, 2012-2019.

\begin{tabular}{|c|c|c|c|c|c|c|c|c|c|c|c|}
\hline \multirow{2}{*}{ Operator \& Zone } & \multirow{2}{*}{ Wells } & \multirow{2}{*}{ Pads } & \multirow{2}{*}{$\begin{array}{l}\text { Wells } \\
\text { per pad }\end{array}$} & \multirow{2}{*}{$\begin{array}{c}\text { Max } \\
\text { Wells } \\
\text { on Pad }\end{array}$} & \multirow{2}{*}{$\begin{array}{l}\text { Pads with } \\
>16 \text { wells }\end{array}$} & \multicolumn{2}{|c|}{ Frack Water $\left(\mathrm{m}^{3}\right)$} & \multicolumn{2}{|c|}{$\begin{array}{l}\text { Associated } \\
\text { Earthquakes }{ }^{1}\end{array}$} & \multicolumn{2}{|c|}{ Land Tenure } \\
\hline & & & & & & Total & $\begin{array}{c}\text { Water per } \\
\text { well }\end{array}$ & Number & Ratio & Crown & Private \\
\hline \multicolumn{12}{|l|}{ KSMMA } \\
\hline OVINTIV & 436 & 44 & 9.9 & 29 & 9 & $6,640,707$ & 15,231 & 38 & $9 \%$ & $1 \%$ & $99 \%$ \\
\hline TOURMALINE OIL & 272 & 50 & 5.4 & 18 & 1 & $2,517,732$ & 9256 & 79 & $29 \%$ & $1 \%$ & $99 \%$ \\
\hline CREW & 136 & 33 & 4.1 & 9 & 0 & $1,723,503$ & 12,673 & 25 & $18 \%$ & $94 \%$ & $6 \%$ \\
\hline ARC RESOURCES & 134 & 28 & 4.8 & 8 & 0 & $1,058,230$ & 7897 & 6 & $4 \%$ & $87 \%$ & $13 \%$ \\
\hline CNRL & 101 & 14 & 7.2 & 14 & 0 & $1,417,423$ & 14,034 & 12 & $12 \%$ & $6 \%$ & $94 \%$ \\
\hline SHELL & 95 & 15 & 6.3 & 17 & 1 & $1,089,170$ & 11,465 & & & $46 \%$ & $54 \%$ \\
\hline LEUCROTTA & 7 & 5 & 1.4 & 2 & 0 & 84,441 & 12,063 & & & $0 \%$ & $100 \%$ \\
\hline PENGROWTH & 6 & 1 & 6.0 & 6 & 0 & 78,476 & 13,079 & & & $100 \%$ & $0 \%$ \\
\hline $\mathrm{ADU}$ & 1 & 1 & 1.0 & 1 & 0 & 18,552 & 18,552 & & & $100 \%$ & $0 \%$ \\
\hline TOTAL KSMMA & 1188 & 191 & 6.2 & 29 & 11 & $14,628,234$ & 12,313 & 160 & $13 \%$ & $29 \%$ & $71 \%$ \\
\hline \multicolumn{12}{|l|}{ NPGMMA } \\
\hline PETRONAS & 536 & 146 & 3.7 & 10 & 0 & $8,262,356$ & 15,415 & 209 & $39 \%$ & $98 \%$ & $2 \%$ \\
\hline PAINTED PONY & 181 & 32 & 5.7 & 12 & 0 & $2,313,755$ & 12,783 & 22 & $12 \%$ & $91 \%$ & $9 \%$ \\
\hline TOURMALINE OIL & 104 & 14 & 7.4 & 18 & 2 & $1,088,761$ & 10,469 & 14 & $13 \%$ & $89 \%$ & $11 \%$ \\
\hline PACIFIC CANBRIAM & 91 & 20 & 4.6 & 13 & 0 & $1,882,962$ & 20,692 & 15 & $16 \%$ & $100 \%$ & $0 \%$ \\
\hline SAGUARO & 74 & 7 & 10.6 & 15 & 0 & $1,120,218$ & 15,138 & 1 & $1 \%$ & $100 \%$ & $0 \%$ \\
\hline BLACK SWAN & 20 & 10 & 2.0 & 5 & 0 & 204,953 & 10,248 & & & $100 \%$ & $0 \%$ \\
\hline ARC RESOURCES & 12 & 3 & 4.0 & 7 & 0 & 279,475 & 23,290 & 2 & $17 \%$ & $92 \%$ & $8 \%$ \\
\hline CNRL & 4 & 3 & 1.3 & 1 & 0 & 30,877 & 7,719 & 1 & $25 \%$ & $75 \%$ & $25 \%$ \\
\hline POLAR STAR & 4 & 2 & 2.0 & 3 & 0 & 50,711 & 12,678 & & & $100 \%$ & $0 \%$ \\
\hline CONOCOPHILLIPS & 2 & 2 & 1.0 & 1 & 0 & 19,886 & 9943 & 3 & $150 \%$ & $100 \%$ & $0 \%$ \\
\hline TOTAL NPGMMA & 1028 & 239 & 4.3 & 18 & 2 & $15,253,954$ & 14,838 & 267 & $26 \%$ & $97 \%$ & $3 \%$ \\
\hline \multicolumn{12}{|l|}{ OTHER } \\
\hline OVINTIV & 134 & 39 & 3.4 & 12 & 0 & $2,584,975$ & 19,291 & & & $16 \%$ & $84 \%$ \\
\hline SHELL & 121 & 19 & 6.4 & 16 & 1 & $1,176,626$ & 9724 & 3 & $2 \%$ & $79 \%$ & $21 \%$ \\
\hline MURPHY & 97 & 27 & 3.6 & 10 & 0 & $1,092,078$ & 11,259 & & & $17 \%$ & $83 \%$ \\
\hline STORM RESOURCES & 67 & 27 & 2.5 & 5 & 0 & 516,979 & 7716 & & & $71 \%$ & $29 \%$ \\
\hline BLACK SWAN & 45 & 9 & 5.0 & 8 & 0 & 511,588 & 11,369 & & & $100 \%$ & $0 \%$ \\
\hline KELT LNG & 39 & 23 & 1.7 & 3 & 0 & 537,672 & 13,786 & 6 & $15 \%$ & $100 \%$ & $0 \%$ \\
\hline TOURMALINE OIL & 37 & 12 & 3.1 & 6 & 0 & 358,733 & 9695 & & & $24 \%$ & $76 \%$ \\
\hline CONOCOPHILLIPS & 20 & 8 & 2.5 & 13 & 0 & $1,228,747$ & 61,437 & 1 & $5 \%$ & $95 \%$ & $5 \%$ \\
\hline
\end{tabular}




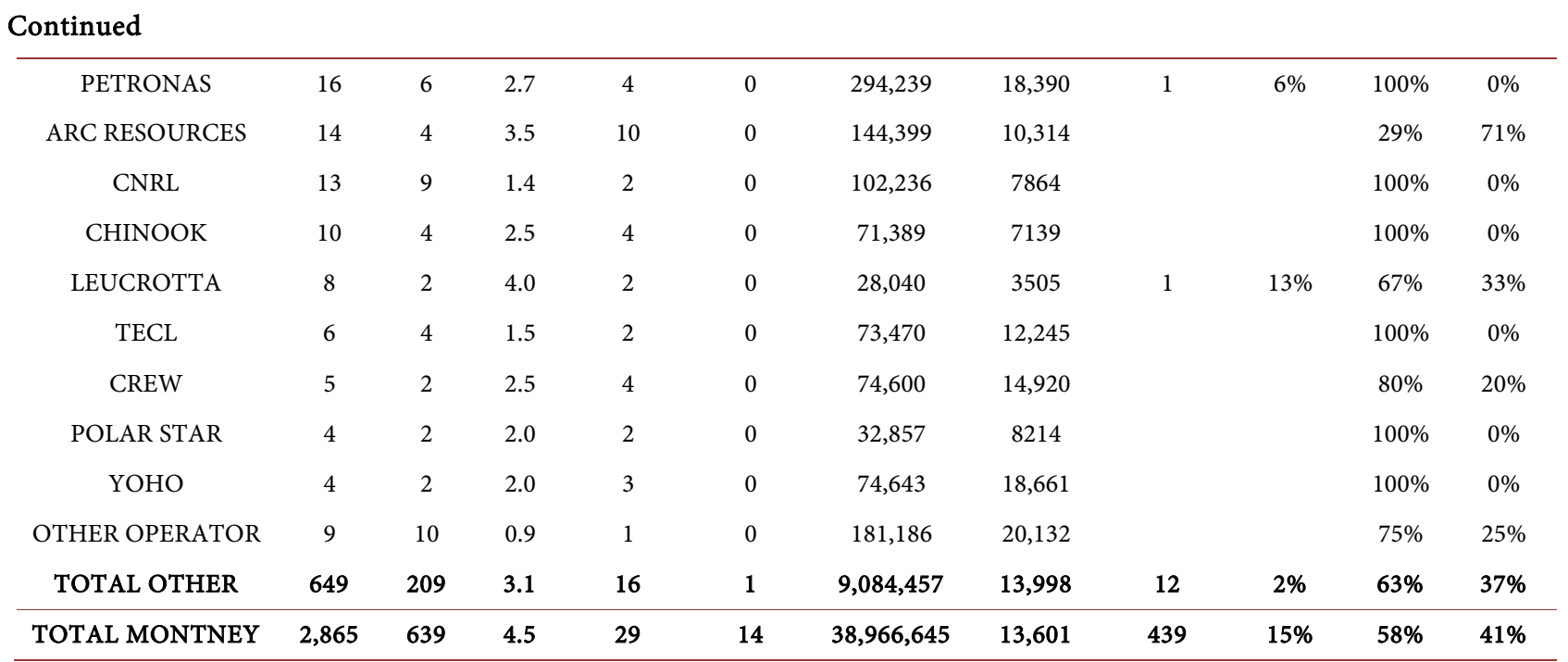

Note 1. Associated earthquakes are for the 2013-2019 period (NRCAN catalogue) and have hydraulically fractured wells within 5-km radius of the earthquake epicentre with fracking in the period up to 90 days before the earthquake.

\section{Earthquakes and Hydraulic Fracturing}

\subsection{Earthquake Frequency}

A significant increase in the frequency of earthquakes $M \geq 3.0$ magnitude appears to have occurred in 2008, shortly after the start of HF activity in the Montney in 2005 (Figure 4). For the Montney in its entirety, the frequency increased from 1.6 earthquakes $(M \geq 3.0)$ per year during 2000-2007, to almost 6.9 per year during 2008-2019, a 4X increase. Most of this change, however, comes from the NPGMMA, going from 0.3 earthquakes $(\mathbf{M} \geq 3.0)$ per year during 2000-2007 to 5.5 per year during 2008-2019, an increase of almost 20X. For the KSSMA, the shift to increased earthquake frequency occurred later, in 2018, going from $0.3 \mathrm{M} \geq 3.0$ earthquakes per year in 2000-2017 to an average of 3.0 per year in 2018-2019, a 10X increase. These changes are all statistically significant (Student's t-test, $p<0.01$ ), although the period of change for the KSMMA is short and should be considered with caution. For the Montney outside the NPGMMA and KSSMA, there is no change in the frequency of earthquakes over the 2000-2019 period.

The number of $\mathbf{M} \geq 3.0$ earthquakes in both the NPGMMA and KSMMA each year are positively correlated with the number of HF wells and the volume of frack water injected each year $\left(\mathrm{R}^{2} \mathrm{adj}=0.40-0.58, p<0.05\right)$ (Figure 5). Also, in the NPGMMA there is a strong positive correlation between the total number of earthquakes each year and the total volume of injected frack fluid $\left(\mathrm{R}^{2} \mathrm{adj}=0.81\right.$, $p<0.01)$. This relationship is not evident in the KSMMA. Increased seismicity rates did not begin in the KSMMA until 2018, delayed from the beginning of HF activity but coinciding with the substantial increase in HF activity in 2017 when accelerated fracking for natural gas liquids began (refer to Figure 2). Schultz et al. (2018) observed a similar delay in the initiation of HF-induced seismicity in the Duvernay Play in Alberta. 


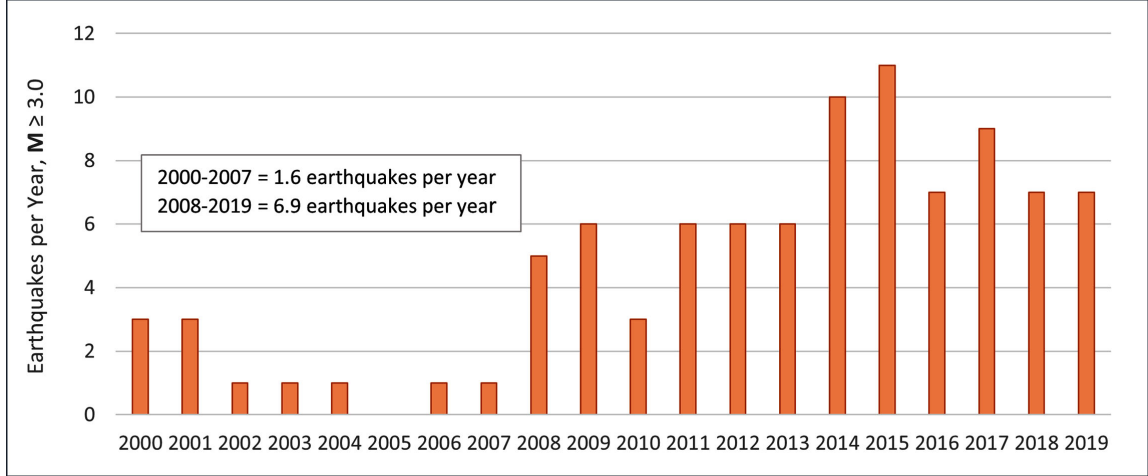

Figure 4. Frequency of earthquakes of magnitude $\geq 3.0$ during 2000-2019 in the Montney Play Trend. The first large volume multistage hydraulic fracturing operation in the Montney occurred in 2005. The 4X increase in frequency from 2000-2007 to 2008-2019 is statistically significant $(p<0.01)$.
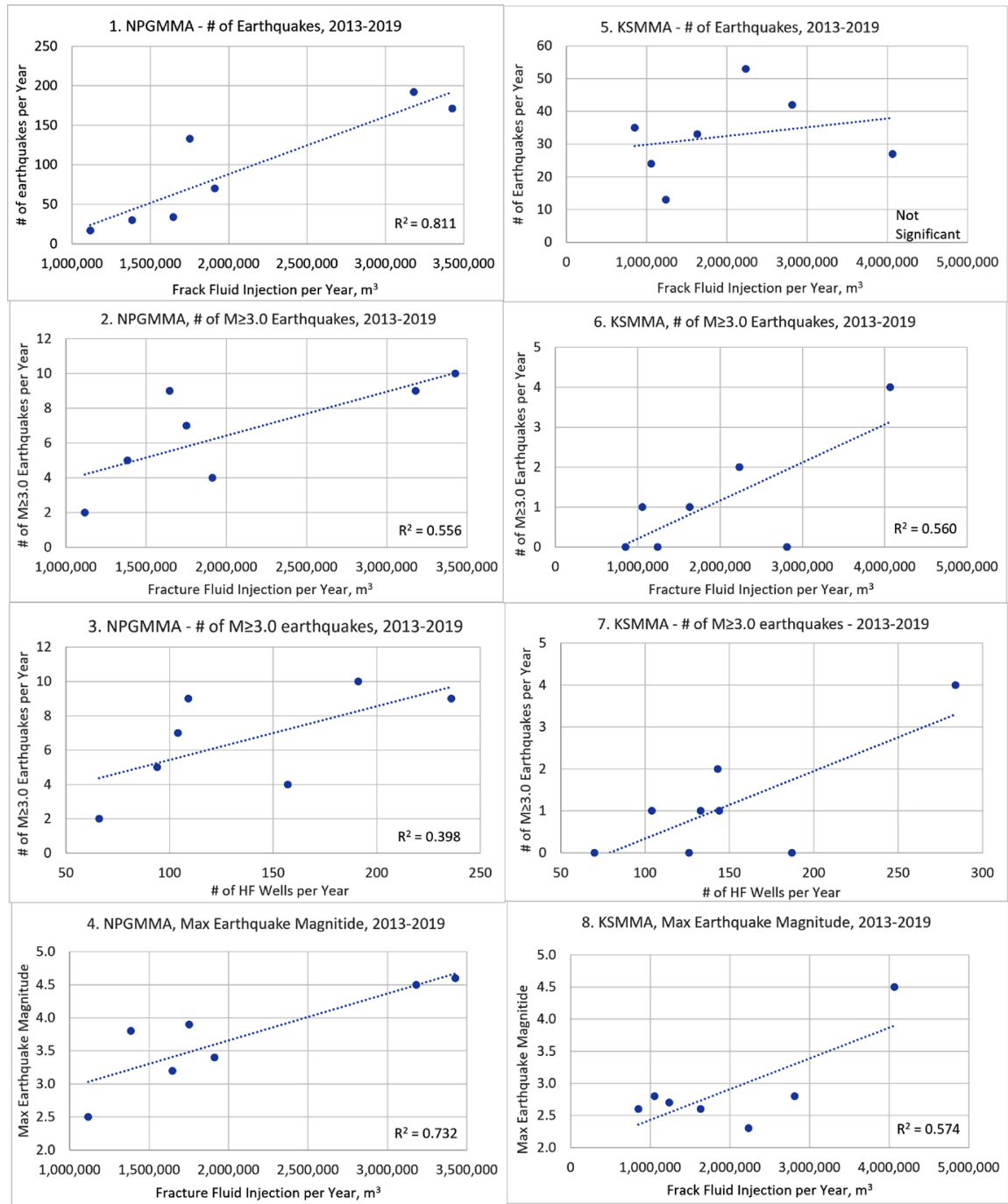

Figure 5. Linear relationships between annual frequency and maximum magnitude of earthquakes in the KSMMA and NPGMMA, and the number of hydraulically fractured wells and injected frack fluid volume per year. All relationships are statistically significant at the $p<0.05$ level or better, unless noted as "Not Significant". 
Of the 975 earthquakes recorded in the Montney during 2013-2019, 439 (50\%) have a close spatiotemporal association with hydraulic fracturing (within a $5-\mathrm{km}$ radius and within 90 days before the earthquake) (refer to Table 1). A total of 751 earthquakes (77\%) have proximal frack fluid injection within 5-km of the epicentre during the previous three years. For the 439 earthquakes with the closest spatiotemporal association with hydraulic fracturing operations, 160 are in the KSMMA, led by Tourmaline Oil with 79 associated earthquakes, Ovintiv with 38, Crew Energy with 25, CNRL with 12 and ARC Resources with 6. Tourmaline Oil and Ovintiv together are associated with $73 \%$ of all the earthquakes in the KSMMA. There were 267 associated earthquakes in the NPGMMA, led by Petronas with 209. Painted Pony, Pacific Canbriam and Tourmaline Oil are far behind, with 22, 15 and 14 associated earthquakes, respectively. Petronas is notable - it alone is associated with $78 \%$ of the earthquakes in the NPGMMA and almost one-half the earthquakes in the entire Montney over the 2013-2019 period.

Of the $56 \mathrm{M} \geq 3.0$ earthquakes that occurred in the Montney over the 2013-2019 period, 30 (54\%) have a clear spatiotemporal association with proximal hydraulic fracturing (Table 2), while 45 (80\%) have proximal frack fluid injection at some time in the three years before the earthquake. The $5-\mathrm{km}$ and 90-day spatiotemporal filter used in this report clearly does not encompass all earthquakes associated with hydraulic fracturing. An additional eight earthquakes have apparent triggering HF operations (discussed below) more distant than $5-\mathrm{km}$ from the earthquake epicentre and are not captured by the $5-\mathrm{km}$ filter. As well, the strong linear relationship between earthquake frequency and annual total frack fluid injection, along with the relationship between $\mathbf{M} \geq 3.0$ earthquakes and their associated antecedent one- to three-year cumulative frack fluid injection (Table 3 ) as discussed below, supports the conclusion that HF association with earthquakes extends beyond the boundaries of a $5-\mathrm{km}$ and 90-day filter. These lead to a conclusion that $\sim 60 \%-70 \%$ of observed $\mathbf{M} \geq 3.0$ seismicity in the Montney is related to hydraulic fracturing activity, a result comparable to Atkinson et al. (2016) and Ghofrani \& Atkinson (2021).

Table 2. Earthquakes in the Montney Trend of magnitude $\left(M_{L}\right.$ or $\left.M_{W}\right) \geq 3.0$ during 2013-2019, with associated HF information. Earthquakes in red have no evident association with HF.

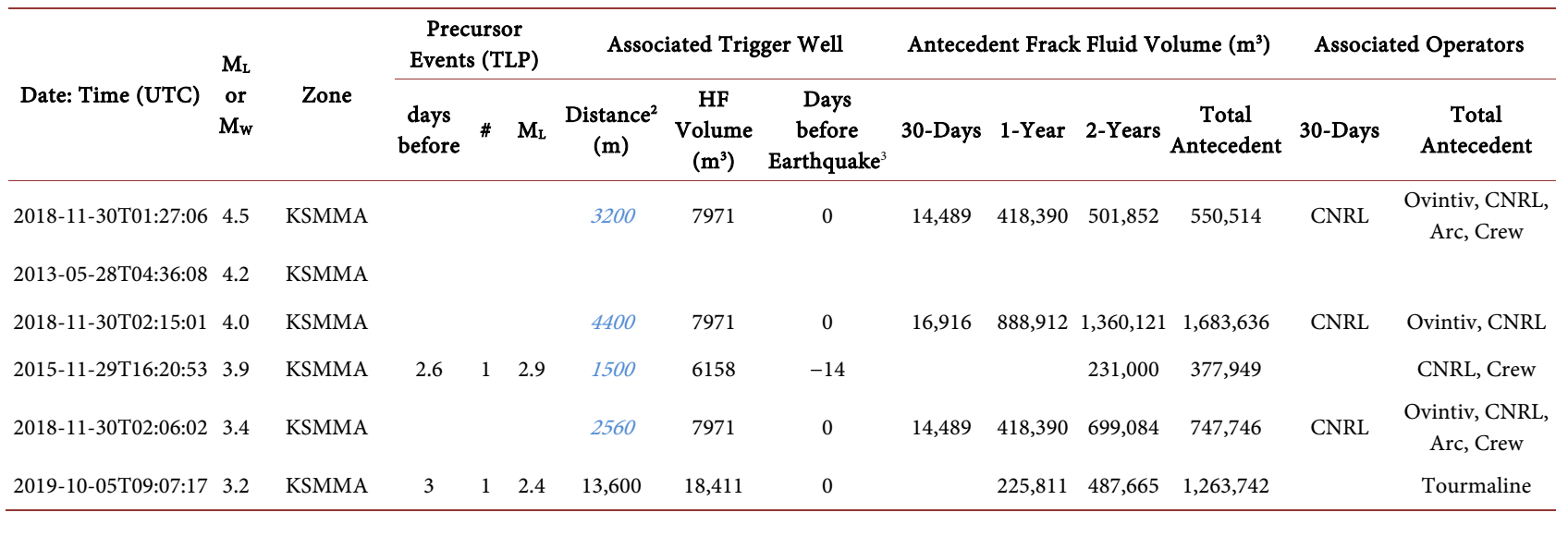




\section{Continued}

\begin{tabular}{|c|c|c|c|c|c|c|c|c|c|c|c|c|c|c|}
\hline 2018-04-30T05:05:57 & 3.0 & KSMMA & & & & & & & & 365,628 & 748,952 & $1,226,684$ & & Crew, CNRL, \\
\hline 2019-10-08T13:44:04 & 3.0 & KSMMA & 6 & 1 & 2.4 & & 16,686 & -2 & & 225,811 & 435,148 & $1,117,636$ & & Tourmaline \\
\hline 2015-08-17T20:15:00 & 4.6 & NPGMMA & & & & 4900 & 10,303 & -1 & 143,187 & 210,592 & 228,346 & 275,706 & Petronas & Petronas \\
\hline 2014-08-04T17:17:24 & 4.5 & NPGMMA & & & & 930 & 11,682 & -2 & 35,548 & 47,202 & 86,694 & 86,694 & Petronas & Petronas \\
\hline 2016-07-12Т21:08:39 & 3.9 & NPGMMA & & & & 2160 & 21,140 & 2 & 69,179 & 142,994 & 142,994 & 168,111 & Saguaro & Saguaro \\
\hline 2019-07-13Т08:59:11 & 3.9 & NPGMMA & 4 & 1 & 2.5 & 3200 & 7215 & 0 & 144,870 & 389,866 & 611,474 & $1,275,452$ & Tourmaline & $\begin{array}{c}\text { Tourmaline, } \\
\text { Petronas }\end{array}$ \\
\hline 2014-07-30T21:23:56 & 3.8 & NPGMMA & & & & 13,600 & 13,724 & 3 & & & 52,707 & 52,707 & & Petronas \\
\hline 2019-11-30T07:32:47 & 3.8 & NPGMMA & & & & 1880 & 7247 & -8 & 98,066 & 292,999 & 292,999 & 735,792 & Tourmaline & $\begin{array}{c}\text { Tourmaline, } \\
\text { Petronas }\end{array}$ \\
\hline 2014-07-16T17:44:06 & 3.7 & NPGMMA & 1 & 1 & 2.4 & 4510 & 11,109 & -1 & & 84,629 & 84,629 & 124,246 & & Petronas \\
\hline 2015-11-03T12:41:05 & 3.6 & NPGMMA & 3 & 2 & 2.2 & 13,900 & 18,513 & -12 & & 39,304 & 39,304 & 39,304 & & Petronas \\
\hline 2014-12-17T10:01:48 & 3.5 & NPGMMA & 24 & 2 & 2.8 & 12,700 & 17,559 & 1 & & & 12,510 & 12,510 & & $\begin{array}{c}\text { Pacific } \\
\text { Canbriam }\end{array}$ \\
\hline 2015-09-02Т07:42:34 & 3.5 & NPGMMA & 16 & 3 & 4.6 & 1570 & 16,087 & 0 & & 108,386 & 153,108 & 153,108 & & Petronas \\
\hline 2016-10-16T03:27:53 & 3.5 & NPGMMA & & & & 5480 & 29,960 & 0 & 29,960 & 90,847 & 90,847 & 299,617 & Petronas & Petronas \\
\hline 2018-01-21T05:48:47 & 3.5 & NPGMMA & & & & & & & & & & 220,638 & & Petronas \\
\hline 2013-04-07T02:39:11 & 3.5 & NPGMMA & & & & & & & & & & & & \\
\hline 2013-08-21T15:31:31 & 3.4 & NPGMMA & 0.4 & 1 & 2.0 & 1850 & 20,189 & -1 & 32,765 & 32,765 & 32,765 & 32,765 & Petronas & Petronas \\
\hline 2015-11-21T17:57:30 & 3.4 & NPGMMA & 4 & 3 & 2.4 & 10,200 & 25,050 & 0 & 75,284 & 310,281 & 397,958 & 448,768 & Petronas & Petronas \\
\hline 2016-12-03Т05:13:55 & 3.4 & NPGMMA & 23 & 1 & 2.3 & 4170 & 25,373 & 0 & 73,636 & 73,636 & 110,863 & 153,314 & Petronas & $\begin{array}{l}\text { Petronas, } \\
\text { Pacific } \\
\text { Canbriam, }\end{array}$ \\
\hline 2014-12-29T15:03:13 & 3.3 & NPGMMA & 12 & 7 & 3.5 & 12,400 & 17,559 & -11 & & & 12,510 & 12,510 & & $\begin{array}{c}\text { Pacific } \\
\text { Canbriam }\end{array}$ \\
\hline 2015-08-28T03:52:18 & 3.3 & NPGMMA & 28 & 1 & 2.1 & & & & & & & 2700 & & $\begin{array}{c}\text { Pacific } \\
\text { Canbriam }\end{array}$ \\
\hline 2019-02-27T16:41:02 & 3.3 & NPGMMA & 7 & 2 & 3.4 & 2220 & 11,308 & -1 & 122,498 & 122,498 & 233,302 & 540,660 & Tourmaline & $\begin{array}{c}\text { Tourmaline, } \\
\text { Petronas }\end{array}$ \\
\hline 2017-06-08T20:22:18 & 3.3 & NPGMMA & & & & & & & & & & & & \\
\hline 2014-03-02Т22:24:23 & 3.2 & NPGMMA & 0.2 & 1 & 2.6 & 2220 & 13,493 & -3 & 13,493 & 13,493 & 13,493 & 13,493 & Petronas & Petronas \\
\hline 2017-10-23Т01:28:27 & 3.2 & NPGMMA & 0.2 & 1 & 3.0 & 6350 & 17,452 & -1 & 67,293 & 132,431 & 231,419 & 378,266 & $\begin{array}{c}\text { Painted } \\
\text { Pony }\end{array}$ & $\begin{array}{c}\text { Painted Pony, } \\
\text { Petronas }\end{array}$ \\
\hline 2016-12-30T00:06:24 & 3.2 & NPGMMA & & & & & & & & & & & & \\
\hline 2017-04-19T19:07:57 & 4.2 & NPGMMA & & & & & & & & & & & & \\
\hline 2014-12-21T00:18:36 & 3.1 & NPGMMA & 27 & 5 & 2.7 & 13,100 & 11,618 & -11 & & & 6870 & 6870 & & CNRL \\
\hline 2015-03-01T11:30:44 & 3.1 & NPGMMA & 9 & 1 & 2.6 & 5780 & 11,500 & -10 & 11,500 & 106,406 & 132,004 & 132,004 & Petronas & $\begin{array}{l}\text { Petronas, } \\
\text { Tourmaline, }\end{array}$ \\
\hline 2016-03-10T02:37:13 & 3.1 & NPGMMA & 3 & 2 & 2.3 & 3040 & 14,405 & -3 & & & 106,406 & 132,004 & & $\begin{array}{c}\text { Petronas, } \\
\text { Tourmaline, }\end{array}$ \\
\hline 2016-11-10T05:58:34 & 3.1 & NPGMMA & & & & & & & & 82,083 & 105,941 & 146,191 & & $\begin{array}{c}\text { Pacific } \\
\text { Canbriam }\end{array}$ \\
\hline 2017-10-27T04:18:03 & 3.1 & NPGMMA & 2 & 1 & 3.0 & 5160 & 15,503 & 0 & & 198,951 & 568,767 & $1,020,982$ & & $\begin{array}{c}\text { Pacific } \\
\text { Canbriam }\end{array}$ \\
\hline 2017-11-15T19:13:19 & 3.1 & NPGMMA & 1 & 1 & 2.2 & 11,200 & 11,272 & 2 & & 158,308 & 254,819 & 525,027 & & $\begin{array}{c}\text { Painted Pony, } \\
\text { Petronas }\end{array}$ \\
\hline 2018-05-19T07:56:45 & 4.1 & NPGMMA & & & & & & & & & & & & \\
\hline
\end{tabular}




\section{Continued}

\begin{tabular}{|c|c|c|c|c|c|c|c|c|c|c|c|c|c|c|}
\hline 2013-10-16T17:46:10 & 3.0 & NPGMMA & 2 & 1 & 2.7 & 1150 & 13,994 & -2 & 77,268 & 77,268 & 77,268 & 77,268 & Petronas & Petronas \\
\hline 2014-01-23Т03:30:04 & 3.0 & NPGMMA & 9 & 9 & 2.7 & 3070 & 16,511 & -2 & 45,702 & 103,531 & 103,531 & 103,531 & Petronas & Petronas \\
\hline 2014-06-30T19:38:46 & 3.0 & NPGMMA & & & & 3330 & 13,340 & -8 & 64,121 & 199,585 & 308,023 & 308,023 & Petronas & Petronas \\
\hline 2015-04-06Т02:34:56 & 3.0 & NPGMMA & 22 & 1 & 2.0 & 4390 & 9143 & -12 & & 22,656 & 96,145 & 121,027 & & $\begin{array}{c}\text { Petronas, } \\
\text { Painted Pony, } \\
\text { Tourmaline }\end{array}$ \\
\hline 2015-09-26Т08:55:16 & 3.0 & NPGMMA & 24 & 4 & 2.8 & 12,700 & 16,473 & 0 & 38,085 & 142,450 & 298,498 & 310,026 & Petronas & Petronas \\
\hline 2016-02-21T09:51:28 & 3.0 & NPGMMA & 15 & 3 & 2.1 & 12,500 & 24,112 & 1 & & 167,831 & 255,508 & 275,900 & & Petronas \\
\hline 2017-10-22T21:26:55 & 3.0 & NPGMMA & 0.1 & 1 & 2.4 & 3230 & 17,452 & 0 & 49,298 & 167,524 & 309,204 & 483,320 & $\begin{array}{l}\text { Painted } \\
\text { Pony }\end{array}$ & Painted Pony \\
\hline 2017-10-25T22:43:28 & 3.0 & NPGMMA & & & & 3270 & 19,944 & 2 & 33,447 & 101,213 & 152,826 & 185,259 & $\begin{array}{c}\text { P. } \\
\text { Canbriam }\end{array}$ & $\begin{array}{c}\text { Pacific } \\
\text { Canbriam }\end{array}$ \\
\hline 2013-01-19T16:35:32 & 3.0 & NPGMMA & 0.3 & 1 & 2.9 & & & & & & & & & \\
\hline 2015-03-21T15:49:20 & 3.0 & NPGMMA & & & & & & & & & & & & \\
\hline 2017-04-21T07:47:09 & 3.0 & NPGMMA & 0.5 & 1 & 3.2 & & & & & & & & & \\
\hline 2018-01-25Т02:31:53 & 3.7 & Other & & & & & & & & & & 22,634 & & ConocoPhillips \\
\hline 2014-03-01T04:35:29 & 3.4 & Other & & & & & & & & & & & & \\
\hline \multirow[t]{3}{*}{ 2013-09-03Т02:45:26 } & 3.3 & Other & & & & & & & & & & & & \\
\hline & $\bar{X}$ & & & & & 5800 & 15,111 & -2 & 59,417 & 183,426 & 255,144 & 369,571 & & \\
\hline & $\operatorname{Max}$ & & & & & 13,900 & 29,960 & -14 & 144,870 & 888,912 & $1,360,121$ & $1,683,636$ & & \\
\hline
\end{tabular}

Note 1. Associated earthquakes have HF activity within $5-\mathrm{km}$ radius of the earthquake and within 90 days before the earthquake occurrence. Note 2 . Distances shown in blue italic are derived from the Visser $(2017,2020)$ earthquake catalogues, the remainder are derived from the NRCAN catalogue. Note 3. "Days before Earthquake" are negative where the fracking completed before the date of the earthquake and are positive where the fracking completed after the earthquake. Where the day is zero (0), the fracking completed on the day of the earthquake.

Table 3. Volumes of injected HF water for Montney earthquakes, 2013-2019, for HF wells located within 5-km radius of the earthquake epicentre. For the results shown in red the $M \geq 3.0$ volumes are significantly larger than the $M \leq 2.9$ volumes (Mann-Whitney $\mathrm{U}, p<0.05)$.

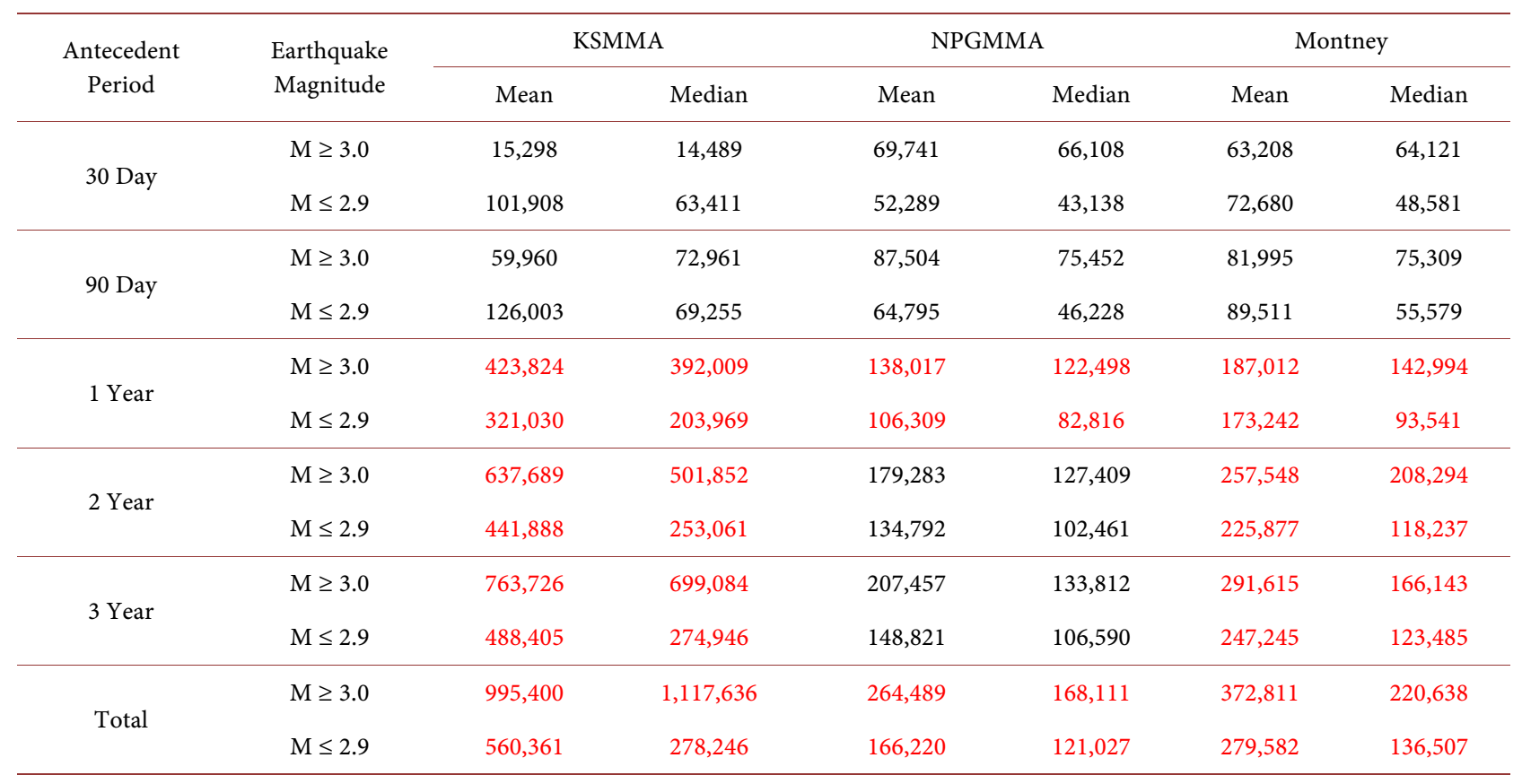


Differences in seismic susceptibility across the Montney are evident. Fifteen percent of hydraulically fractured wells in the Montney during 2012-2019 have close spatiotemporal association with earthquakes. The NPGMMA has the highest rate of induced seismicity, with $26 \%$ of HF wells associated with earthquakes, while the rate in the KSMMA is about one-half that, at $13 \%$. The remainder of the Montney outside these two zones appears to have a low susceptibility to HF-induced earthquakes, with a rate of only $2 \%$. Also, there are clear differences in associated earthquake rates among operators, possibly indicative of geologic and tectonic differences across the Montney and within the zones, and possibly also related to differences in hydraulic fracturing procedures (pump rate, volume per stage, etc.). Petronas leads with the highest earthquake rate - 39\% of its HF wells are associated with earthquakes, followed by Tourmaline Oil in the KSMMA with an associated earthquake rate of $29 \%$. Ovintiv, the largest operator in the KSMMA, has an associated earthquake rate that is one-third of Tourmaline's, at 9\% (refer to Table 1 ).

The rate of association of $\mathbf{M} \geq 3.0$ earthquakes with HF wells is $1.7 \%$ for the Montney in total, ranging from $3.9 \%$ for the NPGMMA to $0.6 \%$ for the KSMMA, and with a rate of $<0.2 \%$ for the remainder of the Montney. As noted above, these should be considered the low range of HF-earthquake association, since there are eight additional $\mathbf{M} \geq 3.0$ earthquakes with triggering HF wells beyond $5-\mathrm{km}$ that were not captured by the $5-\mathrm{km}$ and 90 -day spatiotemporal filter used in this analysis. These are comparable to the association rates reported by Ghofrani and Atkinson $(2020,2021)$ across the Western Canada Sedimentary Basin but are higher than those of Atkinson et al. (2016). Ghofrani and Atkinson (2020) consider the Montney as a single unit. It would be beneficial to future research to consider the substantial differences in seismogenicity within the Montney, likely related to differences in the geologic foundation that is producing earthquakes in response to large volume frack fluid injection.

\subsection{Earthquake Magnitude}

Both the NPGMMA and KSMMA exhibit linear relationships between the maximum earthquake magnitude each year and the annual volume of injected frack fluid $\left(\mathrm{R}^{2} \mathrm{adj}=0.57-0.73, p<0.05\right)$ (refer to Figure 5). This is a key consideration, given that the unconventional petroleum development in the Montney to date has been limited, with the number of wells and the volumes of frack fluid injection per pad to date well below the levels anticipated at full development.

Cumulative antecedent HF injection volume appears to be an important factor for inducing $\mathbf{M} \geq 3.0$ earthquakes. Table 3 presents the mean and median HF fluid volumes for the 30-day, 90-day, 1-year, 2-year, 3-year and total cumulative periods associated with earthquakes in the Montney, separated into categories of $\mathbf{M} \geq 3.0$ and $\mathbf{M} \leq 2.9$. The data show no statistical association between earthquake magnitude and frack fluid volume for just the 30-day and 90-day periods. 
However, beginning at the 1-year antecedent period the $\mathbf{M} \geq 3.0$ earthquakes are associated with substantially larger cumulative frack water volumes compared to the $\mathbf{M} \leq 2.9$ events (Figure 6). The differences for the 1-year, 2-year, 3-year and total antecedent periods for the KSMMA are all statistically significant (Mann-Whitney $\mathrm{U}$ test, $p<0.05$ ), while the differences in just the 1-year and total antecedent periods are significant for the NPGMMA. As well, $\mathbf{M} \geq 3.0$ earthquakes are associated with a significantly greater number and density of proximal HF wells ( 87 wells within 5-km, 1.10 wells $/ \mathrm{km}^{2}$ ) compared to $\mathrm{M} \leq 2.9$ earthquakes ( 45 wells within $5-\mathrm{km}, 0.57$ wells $/ \mathrm{km}^{2}$ ) (Table 4$)$. The NPGMMA also exhibits a greater number of $\mathrm{HF}$ wells proximal to $\mathbf{M} \geq 3.0$ earthquakes (17 wells within $5-\mathrm{km}, 0.22$ wells $/ \mathrm{km}^{2}$ ) compared to $\mathbf{M} \leq 2.9$ earthquakes (11 wells within $5-\mathrm{km}, 0.14$ wells $/ \mathrm{km}^{2}$ ). These differences are statistically significant (MannWhitey $\mathrm{U}, p<0.05)$. Proximal HF well density and antecedent frack fluid injection volumes are co-related variables. Earthquakes induced by hydraulic fracturing cannot be considered just in relation to a single HF well but must be considered as an outcome related to the cumulative development density from multiple proximal operators and cumulative fluid injection over periods ranging from a few months to a few years.

In most cases of HF-associated earthquakes in the Montney, a single operator was responsible for all the HF activity within 90 days of the earthquake (97\%). However, for 1-year and longer antecedent periods multiple operators in proximity are commonly linked to induced earthquakes. As many as $29 \%$ percent of the Montney earthquakes are associated with hydraulic fracturing conducted by multiple operators over antecedent time periods of one year and longer, in some cases as many as four operators. The KSMMA, where there is a greater density of HF development to date, exhibits the highest rate of multiple operator association with earthquakes, at 59\%. The NPGMMA, which has a lower density of development, has as many as $19 \%$ of earthquakes with multiple operator association. The smaller percentage of co-association in the NPGMMA is mostly due to the dominance of Petronas and the lack of adjacency between them and other operators.

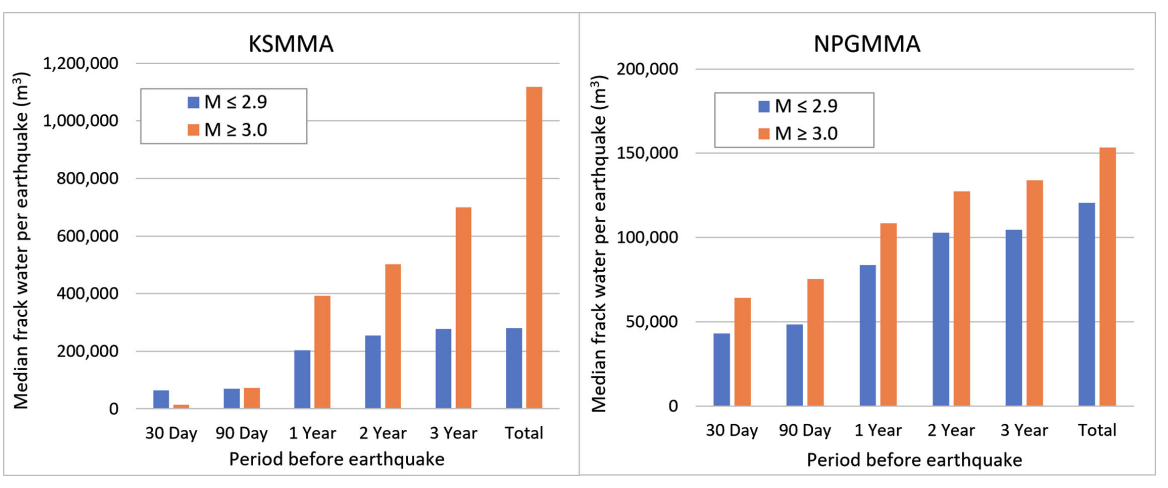

Figure 6. Median frack water volume $\left(\mathrm{m}^{3}\right)$ injected within 5-km of earthquake epicentres for all earthquakes, 2013-2019. 
Table 4. Number and density of HF wells located within 5-km radius of earthquakes. For the results shown in red the $M \geq 3.0$ values are significantly greater than the $M \leq 2.9$ volumes (Mann-Whitney $\mathrm{U}, p<0.05)$.

\begin{tabular}{cccccccc}
\hline \multirow{2}{*}{ Variable } & $\begin{array}{c}\text { Earthquake } \\
\text { Magnitude }\end{array}$ & \multicolumn{2}{c}{ KSMMA } & \multicolumn{2}{c}{ NPGMMA } & \multicolumn{2}{c}{ Montney } \\
\cline { 3 - 7 } & Mean & Median & Mean & Median & Mean & Median \\
\hline \# of wells & $\mathrm{M} \geq 3.0$ & 87 & 100 & 18 & 10 & 29 & 12 \\
within 5-km & $\mathrm{M} \leq 2.9$ & 45 & 31 & 11 & 9 & 21 & 10 \\
Well Density & $\mathrm{M} \geq 3.0$ & 1.10 & 1.27 & 0.23 & 0.13 & 0.37 & 0.15 \\
Wells/km & & & & & & & 0.13 \\
\hline
\end{tabular}

The three earthquakes that occurred on 29 November $2018\left(\mathbf{M}_{\mathrm{W}} 4.6,4.0\right.$ and 3.4) provide a good example of multiple operator association. They were closely associated with nearby well completion operations conducted by CNRL, where $14,489 \mathrm{~m}^{3}$ of frack water was injected by CNRL into two horizontal wells (CNRL HZ Septimus G05-22-081-18 and H05-22-081-18) on a nearby well pad in the preceding 7-day period. However, before that, a total 1.72 million $\mathrm{m}^{3}$ of frack water was injected within $5-\mathrm{km}$ radius of the three earthquake epicentres in a total of $109 \mathrm{HF}$ wells associated with four operators, led by Ovintiv (76 wells, 1.26 million $\mathrm{m}^{3}$ ), followed by CNRL (25 wells, 425,318 $\mathrm{m}^{3}$ ), ARC Resources (8 wells, 41,009 $\mathrm{m}^{3}$ ) and Crew Energy (1 well, $7653 \mathrm{~m}^{3}$ ). Injected frack water can migrate some distance through preferential pathways such as the natural geologic fault and fracture structure, increasing pore pressures well beyond the proximity of the horizontal well bore (Atkinson et al. 2016; Schultz et al., 2015; Atkinson et al. 2020). This geologic co-mingling of HF water from multiple operators or from a single operator across a large geographic space and over varying antecedent time periods makes difficult the task of ascertaining earthquake cause and effect and makes difficult the determination of linkage to a specific HF operation. Also, it indicates that fracking-induced earthquakes are a cumulative development effect with responsibility commonly shared amongst several operators injecting large volumes of frack fluids, or a single operator injecting frack fluids at multiple wells and/or well pads, within geographic bounds.

\subsection{Triggering Events and Precursor Events}

The Montney data indicate that most of the $\mathbf{M} \geq 3.0$ earthquakes are triggered by fracking of a single well, or a small group of wells on a single well pad, in the days before the earthquake. Eighty-seven percent for the Montney $\mathbf{M} \geq 3.0$ earthquakes have associated HF events that appear likely to be the triggering events, with fracking occurring up to 14 days before the earthquake $(\bar{X}=2$ days), with distances ranging from $0.9 \mathrm{~km}$ to $15.0 \mathrm{~km}(\bar{X}=5.8 \mathrm{~km})$. These are associations rather than deterministic cause and effect, and uncertainty increases for the earthquakes with the most distant triggers. If the events with trigger distances of $>10 \mathrm{~km}$ were discounted, the association rate drops to $\sim 70 \%$, similar to 
the rate determined from the spatiotemporal filter analysis concluded above. The mean triggering frack fluid volume is $15,100 \mathrm{~m}^{3}$ (refer to Table 2), representing only $4.3 \%$ percent of the total cumulative antecedent frack fluid injection in the $5-\mathrm{km}$ radius proximal to the earthquake. Sixty-four percent of the triggering wells are located within 5-km of their earthquake epicentre, an approximate maximum length of the horizontal well bore combined the adjacent hydraulically fractured rock, indicating that direct hydraulic intersection of the horizontal well bore with a natural fault or fracture is not a primary causative factor for about one-third of induced earthquakes. There is uncertainty in the locations of earthquake epicentres that needs to be considered. Comparison of the earthquake epicentres between the NRCAN catalogue and the Visser et al. (2017, 2020) catalogues for $\mathbf{M} \geq 3.0$ events indicate epicentral differences of 1.3 - 9.7 $\mathrm{km}(\bar{X}=4.5 \mathrm{~km}$, S.D. $=2.6 \mathrm{~km}, \mathrm{n}=26)$. The variability is random and non-systematic. The improved epicentral locations from the Visser $(2017,2020)$ catalogues cause about one-half the earthquakes to increase in distance from the HF trigger wells and one-half to decrease in distance compared to the NRCAN epicentres, with no net aggregate change. Ten (24\%) of the $M \geq 3.0$ earthquakes have two or more operators fracking proximal to the epicentre at the time of the earthquake. This operational overlap, combined with the epicentre location uncertainty and ambiguity, makes difficult the task of determining triggers and operator responsibility, should that be necessary.

Of the 30 Montney earthquakes $\mathbf{M} \geq 3.0$ identified as closely associated with proximal HF activity (within 5-km of epicentre in previous 90 days), 19 (63\%) have smaller precursor earthquakes (refer to Table 2), based on the NRCAN catalogue. One of the $\mathbf{M} \geq 4.0 \mathrm{HF}$-associated earthquakes had smaller precursor earthquakes that would have provided an early warning. For the KSMMA, only three of seven (43\%) HF-associated earthquakes had smaller precursor events. It is evident that large magnitude induced earthquakes can and do occur without precursor warning.

\subsection{Cumulative Antecedent Frack Fluid Injection}

Cumulative frack fluid injection across extended time periods is a factor in creating the conditions amenable to initiating large magnitude earthquakes. This is possibly due to the dispersion of frack fluid and the diffusion of pore pressures through the existing fault and fracture network (Schultz et al., 2015; Atkinson et al., 2016; Atkinson et al., 2020; Dusseault \& McLennan, 2011), creating an expansive geographic area of increased pore pressure, enhancing the potential for the faults and fractures to experience a slip in relation to a later smaller volume frack fluid injection associated with a single nearby well. This may also be an explanatory hypothesis for the observation of Schultz et al. (2018) of a 3-year delayed response in earthquake rates in the Duvernay Play in Alberta in relation to the beginning of HF activity. This delayed response to earthquake rates is location and geology dependent and is evident in the KSMMA but is less evident in 
the NPGMMA, where accelerated earthquake activity parallels the beginning of HF operations in 2007-2008. This analysis speculatively suggests that the large fracture fluid injection across the KSMMA (13.9 million $\mathrm{m}^{3}$ during 2012-2019) and NPGMMA (14.4 million $\mathrm{m}^{3}$ during 2012-2019) may now have increased the internal pore pressures broadly to enhance potential for increased earthquake frequency and magnitudes in response to ongoing and future HF operations. A seismogenicity role for antecedent frack fluid injection volumes has been noted by recent researchers (e.g., Kao et al., 2018), but the long-term implications remain uncertain.

\section{Discussion}

This study documents that earthquake frequency and magnitude increase in response to the number of wells fracked each year and in relation to the volume of injected frack fluid. As well, cumulative frack fluid injection over one- to three-year antecedent time periods, often by multiple operators in proximity, appears to be related to induced seismicity. Co-mingling of injected frack water over antecedent periods of one year or longer is an induced seismicity risk factor, possibly through the diffusion of frack fluid through permeable pathways from adjacent but proximal operations, creating broad geographic areas of elevated pore pressures. The three earthquakes $\left(M_{W} 4.6,4.0\right.$ and 3.4) occurring on 29 November 2018 in the KSMMA provide a good reference case of the cumulative development effect of large volume frack water injection over an antecedent one- to three-year period by multiple operators in a small area (Figure 7(a)). The earthquakes were closely associated with nearby well completion operations conducted by CNRL, where $14,489 \mathrm{~m}^{3}$ of frack water was injected into two horizontal wells immediately before the earthquakes. However, this seems to be the proverbial "straw that broke the camel's back". Before that, a total 1.72 million $\mathrm{m}^{3}$ of frack water was injected within 5-km radius of the three earthquake epicentres in a total of $109 \mathrm{HF}$ wells associated with four operators, led by Ovintiv and followed by CNRL, ARC Resources and Crew Energy. In the NPGMMA, only $16 \%$ of the fracking-associated earthquakes are associated with multiple operators, but this may be more to do with Petronas being the largest tenure holder in the NPGMMA, with most of its HF activity to date being internal in its lease, not at the peripheries close to other operators. The $\mathbf{M}_{\mathrm{w}} 4.6$ earthquake on 17 August 2015 provides a good reference case of cumulative antecedent HF fluid injection by a single operator triggering an earthquake. For this event, Petronas was the sole operator, injecting $67,625 \mathrm{~m}^{3}$ of frack fluid into four wells in the week before the earthquake (Petronas HZ Town A-E099-J/094-B-16, A-F099-J/094-B-16 and A-G099-J/094-B-16), but injecting 275,000 $\mathrm{m}^{3}$ of frack fluid in the three years prior to the earthquake (Figure $7(b)$ ). There is no reason to conclude that the co-mingling effect of cumulative antecedent frack water injections from multiple well pads in initiating earthquakes is not universal across the Montney. Although one-year and longer antecedent frack water volume is 
related to earthquake magnitude, there is no statistically significant difference in the 30-day and 90-day antecedent volume between the $\mathbf{M} \geq 3.0$ and $\mathbf{M} \leq 2.9$ events. The characteristics of the specific HF operation that triggers the earthquake may be less important than the cumulative effect of frack water injections into the subsurface over a longer antecedent period, although this needs to be investigated in light of clear differences in induced earthquake association rates amongst operators.
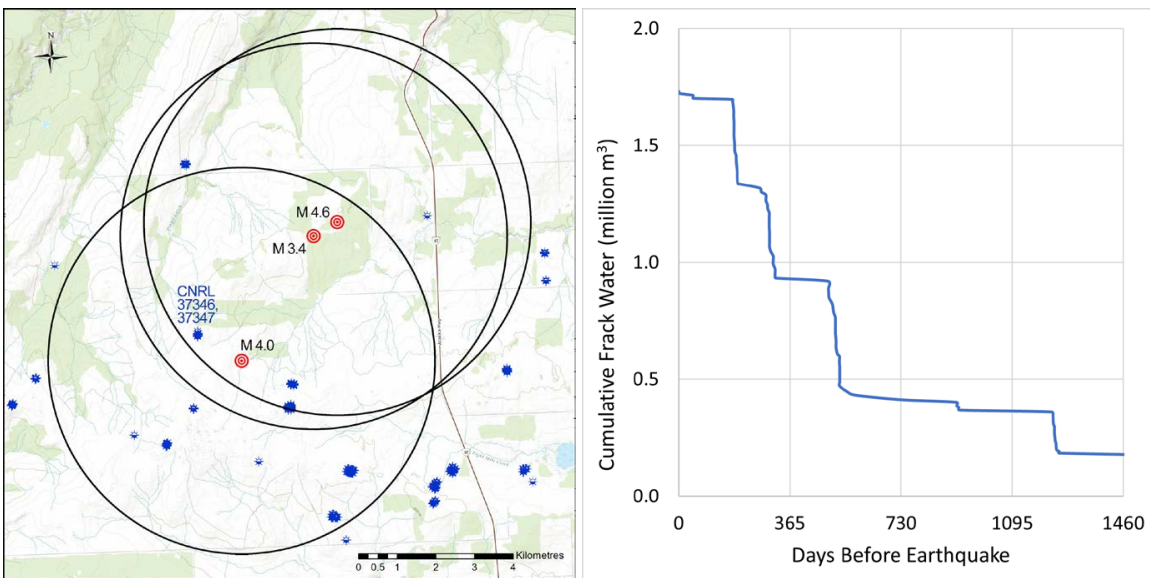

(a)
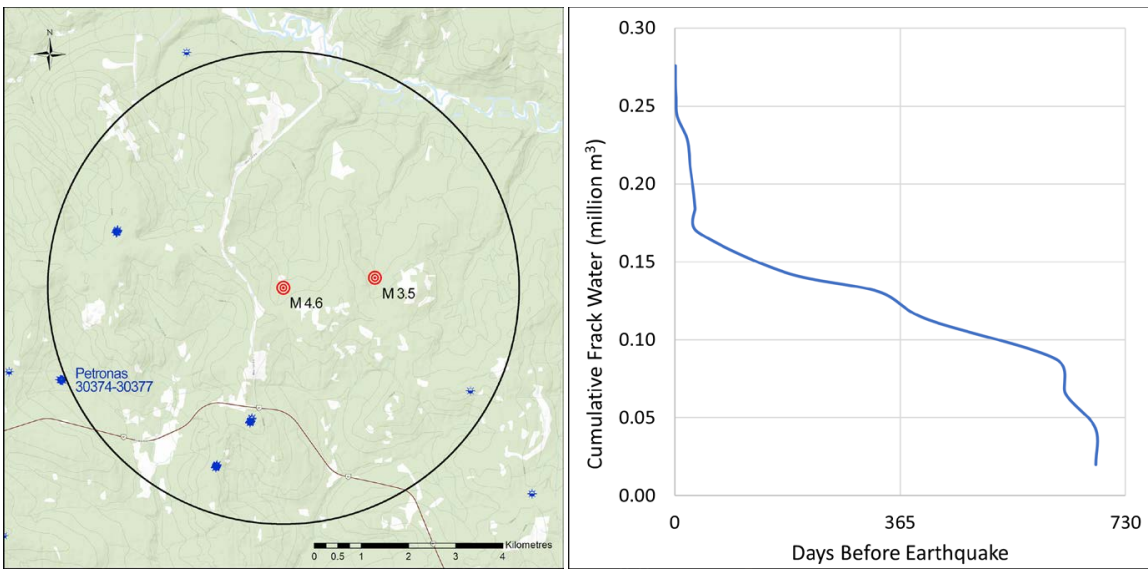

(b)

Figure 7. (a) Locations of the M 4.6 earthquakes and the subsequent M 4.0 and M 3.4 earthquakes (NRCAN catalogue) in the KSMMA on 29 November 2018, showing the $5-\mathrm{km}$ radius buffer around each earthquake and well pads with all hydraulically fractured wells. The two CNRL wells (WA 37346 and 37347) that were being fracked at the time of the earthquakes are shown. There were $109 \mathrm{HF}$ wells within $5-\mathrm{km}$ of the earthquake epicentres fracked before the earthquake, with a total fluid injection of 1.7 million $\mathrm{m}^{3}$; (b) Locations of the M 4.6 earthquake (NRCAN catalogue) in the NPGMMA on 17 August 2015 , with a 5-km radius buffer around the earthquake and well pads with all hydraulically fractured wells. The four Petronas wells (W30374, 30375, 30376 and 30377) that were being fracked at the time of the earthquake are $5.1 \mathrm{~km}$ from the epicentre. There were $16 \mathrm{HF}$ wells fracked within 5.1-km of the earthquake epicentre before the earthquake, with a total fluid injection of $275,000 \mathrm{~m}^{3}$. The M 3.5 earthquake on 02 September 2015 is also shown. 
Eighty-seven percent for the Montney $\mathbf{M} \geq 3.0$ earthquakes have associated HF events that appear likely to be the triggering events, with fracking occurring up to 14 days before the earthquake ( $\bar{X}=2$ days), with distances ranging from $0.9 \mathrm{~km}$ to $15.0 \mathrm{~km}(\bar{X}=5.8 \mathrm{~km})$. The distances between the HF trigger and the earthquakes indicates that direct hydraulic connection between the fractured zone around the well bore and the fault that ruptures due to HF-induced local pore pressure increase is the primary causative factor but is not the only factor. Other causative factors must be considered, such as hydraulic fluid migration for moderate distances along the high-permeability pathways created by the naturally faulted and fractured matrix (Atkinson et al., 2016; Schultz et al., 2015), poroelastic coupling (Goebel et al, 2017) and aseismic slip (Guglielmi et al., 2015). For these three long-distance coupling mechanisms, the role of antecedent cumulative large volume frack fluid injection as presented in this paper is critical.

Given the relationships between earthquake frequency and magnitude and cumulative frack water injection, it is important to consider the state of unconventional petroleum operations in the Montney at the present time. To date, with an average of only 4.5 wells per pad, well below the $20+$ wells per pad anticipated at full development and as being employed in some cases in the KSMMA, the Montney is largely in an early phase of development. Activity has been constrained by the low market value of methane (natural gas). Future unconventional petroleum development in the Montney is likely to remain challenged until economic factors change, which could occur with the completion of the Coastal Gaslink pipeline from Dawson Creek to Kitimat, and the LNG Canada export facility at Kitimat in the mid-2020s (Shell, 2020). At that time, accelerated well drilling and fracking may occur, primarily by completing work on the existing well pad infrastructure. An additional 10,000+ HF wells would be required for the Montney to fill-out the well pads currently built, with a total water requirement of $\sim 230+$ million $\mathrm{m}^{3}$, almost $6 \mathrm{X}$ greater than the total frack fluid injected during 2012-2019, and equivalent to the water volume of as many as 100,000 Olympic-sized swimming pools.

This paper does not include analysis of potential induced seismicity associated with the operation of fluid disposal wells in the Montney. Review by the BC Oil and Gas Commission BCOGC (2014) concluded that about 16 percent of induced earthquakes (M 2.4 - 4.4) were likely associated with disposal wells, while $84 \%$ were associated with fracking activity. Ghofrani and Atkinson (2021) conclude similarly. It is possible that some of the earthquakes reported here as associated with fracking may have a sole or co-association with fluid injection from disposal wells, but it is well documented that hydraulic fracturing is the dominant source of induced earthquakes in the Montney (Ghofrani \& Atkinson, 2021; Schultz et al., 2020a).

\subsection{Public Safety and Infrastructure Risks}

Fracking-induced earthquakes in the Montney and elsewhere will continue to be 
a pervasive issue with ongoing public safety, infrastructure and environmental risks (Atkinson et al., 2020; Ghofrani \& Atkinson, 2020; Schultz et al. 2020a; Schultz et al., 2018; Atkinson et al., 2016; others). Should the rate of HF well development increase in the future, both the frequency of earthquakes and the magnitude of earthquakes are anticipated to rise. There is ongoing debate within the scientific community (e.g., McGarr, 2014; Atkinson et al., 2016; Eaton \& Igonin, 2018) as to what the maximum magnitudes of HF-induced earthquakes might be, with a coalescing of thought towards maximum earthquake magnitude being limited only by the tectonic environment in which the HF activity is occurring, with a probabilistic distribution of magnitudes within that environment (van der Elst et al., 2016). High magnitude and low probability events exceeding $\mathbf{M}_{\mathrm{L}} 5.0$ would be anticipated for the Montney, with the likelihood of events of this magnitude increasing in direct relation to the volume of frack fluid injection and the number of HF-induced earthquakes each year. It is useful to consider the $2018 \mathrm{M}_{\mathrm{L}} 5.7$ and $2019 \mathrm{M}_{\mathrm{L}} 5.3$ earthquakes induced by hydraulic fracturing in China's Sichuan region, which resulted in two deaths, injuries to 17 people, collapse or extensive damage to $390+$ houses, large scale landslides and \$10 million (Can \$) in direct economic impacts (Lei et al., 2019; Rogers, 2020). Induced earthquakes of these magnitudes occurring in some parts of the Montney could be similarly consequential. Recent research by Barbaie Mahani et al. (2019) and Atkinson (2020) on the intensity of ground motion from induced earthquakes concludes that peak ground motions exceed the damage threshold within $5 \mathrm{~km}$ of the earthquake epicentre for $\mathbf{M} 4$ earthquakes, and that ground motions associated with $\mathrm{M} \geq 4.5$ earthquakes have significant damage potential within $5 \mathrm{~km}$ and may be damaging to greater distances. Atkinson (2020) also concludes that earthquakes of $\mathbf{M}>4.8$ can produce significant damage effects from intense ground motion that extends to $10 \mathrm{~km}$ from the earthquake epicentre.

Public risks in the Montney includes the communities of Dawson Creek, Fort St. John, Taylor, Hudson's Hope, Upper Halfway (Halfway River First Nation) and possibly others, and infrastructure such as the WAC Bennett, Peace Canyon and Site $\mathrm{C}$ dams, community water supply and treatment systems, the Taylor Gas Plant, the Taylor Bridge crossing of the Peace River, numerous earthen water storage dams, and others. Table 5 lists the number and magnitudes of earthquakes within $15 \mathrm{~km}$ of some communities and critical infrastructure during 2013-2019, to indicate some of the hazard associated with HF-induced earthquakes at these locations. Included in Table 5 are summary statistics for 25 earthen water storage dams built by petroleum companies, where the dam height is 8 - $23 \mathrm{~m}$, and/or the live storage volume (i.e., the volume that could be released in the event of a dam failure) is 75,000 - 200,000+ $\mathrm{m}^{3}$, where a dam failure could result in public safety and/or environmental impacts. Nineteen of the 25 dams are in the NPGMMA, operated by Petronas, with uncertain design and construction (Parfitt, 2017), while six are in the KSMMA, four operated by Ovintiv and two by ARC Resources. 
Table 5. Number and maximum magnitude of earthquakes within $15-\mathrm{km}$ of communities and critical infrastructure during 2013-2019. These locations (and others) could be considered for protection with "Earthquake Protection Zones".

\begin{tabular}{|c|c|c|c|}
\hline Location & Zone & $\begin{array}{c}\text { \# of } \\
\text { Earthquakes }\end{array}$ & $\begin{array}{c}\text { Maximum } \\
\text { Magnitude } \\
\left(\mathrm{M}_{\mathrm{L}} \text { or } \mathrm{M}_{\mathrm{w}}\right)\end{array}$ \\
\hline Dawson Creek & KSMMA & 10 & 2.5 \\
\hline Fort St. John & KSMMA & 5 & 4.2 \\
\hline Taylor (including Taylor Bridge and Gas Plant) & KSMMA & 35 & 4.6 \\
\hline Hudson's Hope & NPGMMA & 1 & 2.5 \\
\hline Upper Halfway (Halfway River First Nation) & NPGMMA & 38 & 3.5 \\
\hline WAC Bennet dam & NPGMMA & 2 & 1.6 \\
\hline Site $\mathrm{C}$ dam $^{1}$ & KSMMA & 12 & 4.2 \\
\hline Petroleum water storage dams $(25 \text { dams })^{2}$ & KSMMA \& NPGMMA & $45(\bar{X})$ & 4.6 \\
\hline
\end{tabular}

Note 1. The epicentres of the $\mathbf{M} 4.6,4.0$ and 3.4 earthquakes on 29 November 2018 were $21-\mathrm{km}$ from the Site $\mathrm{C}$ dam site and are not included in this table. Note 2. For the 25 petroleum water storage dams analyzed in this paper, proximal earthquake counts ranged from 3 to 119 within $15-\mathrm{km}$ of the dam $(\bar{X}=45)$. Eighty percent of the dams have proximal earthquakes $M \geq 3.0$, and $24 \%$ have proximal earthquakes $M \geq$ 4.0 .

\subsection{Hazard Mitigation}

To carry out hydraulic fracturing operations effectively and safely, potentially destructive earthquakes must be mitigated or avoided (Atkinson et al., 2020). Hazard mitigation for induced seismicity in NEBC is predominantly through the possible varying of operator-specific practices such as the duration of injection, the injection pressure and the volume of injected frack fluid, etc., in combination with a Traffic Light Protocol system. Despite being suggested as a mitigation approach by the BCOGC (2014), substantially modifying operator-specific HF practices to reduce earthquake inducement appears unlikely, given that a fundamental basis of the hydraulic fracturing process is to apply a high degree of brute force to create extensive fracturing in the target formation in order to generate economic petroleum production. As well, there is no documentation indicating that modified HF practices to reduce induced earthquake frequency or magnitude have been applied or tested; there is a common tendency of industry operators to hold information as proprietary where they consider that it provides a competitive advantage; and there is no regulatory requirement for modified HF practices to address earthquake risk. Given that, the primary hazard mitigation applied in NEBC is a modified Traffic Light Protocol (TLP) system. TLP systems have become the de facto mitigation approach created by regulatory agencies to address HF-induced earthquakes; despite this, little work has been done to rigorously evaluate the efficacy of their application (Schultz et al., 2020a). The primary TLP which applies to the Montney is contained within regulation under the BC Oil and Gas Activities Act, specifying suspension of HF activity if the HF well is identified as causing a seismic event of $\mathbf{M} 4.0$ or greater 
within 3-km of the HF well (BCGOV, 2020b). The KSMMA (only 9\% of the Montney) has an enhanced TLP created by Order (BCOGC, 2018), specifying suspension of HF activity if a HF well is identified as causing a seismic event of M 3.0 or greater (red light), and initiating use of a mitigation plan if the HF activity is responsible for inducing an earthquake of $\mathbf{M} 2.0$ or greater (orange light). Although conceptually simple and operationally easy, it is not evident that TLPs are sufficient for mitigating the potential for large magnitude induced earthquakes (Atkinson et al., 2020). A number of issues limit the benefit of the British Columbia TLP Order for the KSMMA and severely limits potential efficacy of the induced seismicity regulation (BCGOV, 2020b):

1) Many induced earthquakes do not have smaller precursor events that would initiate the orange light. For the 30 Montney earthquakes $\mathbf{M} \geq 3.0$ identified as associated with proximal HF activity, only 19 (63\%) have smaller precursor earthquakes (refer to Table 2). Large magnitude HF-induced earthquakes can and do occur without precursor warning.

2) The TLP created under regulation (BCGOV, 2020b) applies only to induced earthquakes within 3-km of the HF activity, excluding more distant earthquakes triggered by $\mathrm{HF}$ activity. Of the $38 \mathrm{M} \geq 3.0$ earthquakes listed in Table 2 where a triggering $\mathrm{HF}$ well can be identified, the average distance between the well and the earthquake epicentre is $5.8 \mathrm{~km}$. Only $26 \%$ of the trigger wells are within $3-\mathrm{km}$ of the earthquake. The $\mathbf{M}_{\mathrm{W}} 4.6$ earthquake of 17 August 2015 in the NPGMMA was induced by Petronas fracking activity $5.1 \mathrm{~km}$ from the earthquake epicentre (based on the NRCAN seismographic network operating at that time). The regulation to suspend HF activity did not apply and was not applied. Petronas continued fracking a further five wells on the pad during the next three weeks, which were associated with a further nine earthquakes, including an $\mathbf{M}$ 3.5 on 02 September 2015.

3) HF-induced earthquakes can occur distant from an initiation point due to diffusion of fluids and pore pressure increases, and induced earthquakes can have multiple companies operating in proximity concurrently. For the Montney $\mathbf{M} \geq 3.0$ earthquakes where an apparent triggering HF well can be identified, the distance between the well and the earthquake epicentre is as great as $10+\mathrm{km}$, and $24 \%$ of earthquakes have two or more operators fracking at the same time proximal to the epicentre, creating difficulty linking the earthquake to the initiation trigger and applying an "orange" light.

4) There is considerable uncertainty and ambiguity in the locating of earthquake hypocentres in real-time that creates uncertainty in the application of a TLP based on a specified distance from a HF operation to an earthquake. For the $26 M \geq 3.0$ earthquakes during 2014-2016 with overlapping records in the NRCAN and Visser (2017) catalogues, the distances between earthquake epicentres were $1.3-9.7 \mathrm{~km}(\bar{X}=4.5 \mathrm{~km})$. For the $\mathbf{M}_{\mathrm{w}} 4.6$ earthquake on 17 August 2015 the distance between the NRCAN and Visser et al. (2017) epicentres was $9.6 \mathrm{~km}$. This uncertainty creates difficulties for operational decisions, difficulties 
for assurance of compliance and enforcement of regulations, and difficulties in determining responsibility and accountability for a damaging earthquake should that be necessary.

5) Large magnitude trailing earthquakes can occur after fracking has been suspended (e.g., following the suspension of fracking with the $\mathbf{M} 4.6$ earthquake on 29 November 2018, two further earthquakes occurred shortly afterwards).

Van der Elst et al. (2016) conclude that injection fluid volumes and parameters can affect the initiation of earthquakes, but that tectonics control earthquake magnitude. The upper limit of earthquake magnitude may be unbounded and determinable only within a frequency-magnitude distribution, but it should not be concluded that the largest HF-induced earthquakes that have occurred in the Montney to date are the largest earthquakes possible. The data and analysis presented in this paper show that HF-induced earthquakes increase in both frequency and magnitude in relation to frack fluid injection volumes, and that there appears to be a cumulative development effect whereby prior frack fluid injection possibly resets the seismic potential in certain tectonic environments to allow for eased earthquake initiation related to future lower volume injections. This suggests that the future in the Montney is not if $\mathbf{M}>5$ earthquakes will occur, but when, with that occurrence possibly without any precursor warning.

\section{Conclusion}

Much knowledge about earthquakes induced by high volume hydraulic fracturing has been gained over the last few years, but substantial uncertainty remains. Ongoing focused research in the direction of Atkinson (2020), Atkinson (2017), Atkinson et al. (2020), Schultz et al. (2020a, 2020b), Kao et al. (2017), Eaton and Igonin (2018), Ghofrani and Atkinson (2020), Barbaie Mahani et al. (2019), and others, is necessary. At the same time, there is clear understanding of significant public safety and infrastructure risks in the Peace River region associated with fracking, and there are clear limits and uncertainties with hazard mitigation. Enhanced hazard mitigation is necessary, including improvements in the usefulness and defensibility of the Traffic Light Protocol system used in northeast BC. The risk-informed strategy of Schultz et al. (2020b, 2021), recognizing TLP heterogeneity for at-risk population and infrastructure across the Montney may be applicable and helpful. As well, an improved TLP system would require enhanced accuracy and precision in public-facing real-time earthquake mapping.

There may be locations and values in NEBC where hazard avoidance, such as no-fracking zones, is essential and necessary (Atkinson, 2017). As noted, the communities and critical infrastructure that require enhanced hazard mitigation or hazard avoidance include the communities of Dawson Creek, Fort St. John, Taylor, Hudson's Hope, Upper Halfway (Halfway River First Nation) and possibly others, and infrastructure such as the WAC Bennett, Peace Canyon and Site C dams, water supply and treatment systems, the Taylor Gas Plant, the Taylor Bridge crossing of the Peace River, etc. This brief discussion suggests that the 
communities of Upper Halfway (Halfway River First Nation), Taylor and Dawson Creek (with their municipal infrastructure such as water supply and sewage treatment plants), along with the Taylor Bridge, the Taylor Gas Plant, the Site C dam and the large number of petroleum water storage dams are of particular concern for damage due to fracking-induced earthquakes. Augmented measures to provide assurance of public safety is critical.

Over the past 15 years, British Columbia's experiment in unconventional petroleum development and large volume hydraulic fracturing of horizontal wells has led NEBC to the sobering distinction of having produced some of the world's largest fracking-induced earthquakes. It is an issue of paramount concern.

\section{Acknowledgements}

The author is grateful for the detailed comments and suggestions provided by three anonymous reviewers, and to Laurie Lee for guiding me on a walk one midsummer morning. As well, the author is grateful to Ben, Tom and Chloe, and to colleagues for numerous discussions on this important topic. Cartography is by David Leversee.

\section{Conflicts of Interest}

The author declares no conflicts of interest regarding the publication of this paper.

\section{References}

Atkinson, G. M. (2017). Strategies to Prevent Damage to Critical Infrastructure Due to Induced Seismicity. Facets, 2, 374-394. https://doi.org/10.1139/facets-2017-0013

Atkinson, G. M. (2020). The Intensity of Ground Motions from Induced Earthquakes with Implications for Damage Potential. Bulletin of the Seismological Society of America, 110, 2366-2377. https://doi.org/10.1785/0120190166

Atkinson, G. M., Eaton, D. W., \& Igonin, N. (2020). Developments in Understanding Seismicity Triggered by Hydraulic Fracturing. Nature Reviews Earth \& Environment, 1, 264-277. https://doi.org/10.1038/s43017-020-0049-7

Atkinson, G. M., Eaton, D. W., Ghofrani, H., Walker, D., Cheadle, B., Schultz, R., Shcherbakov, R., Tiampo, K., Gu, J., Harrington, R. M., Liu, Y., van der Baan, M., \& Kao, H. (2016). Hydraulic Fracturing and Seismicity in the Western Canada Sedimentary Basin. Seismological Research Letters, 87, 631-647. https://doi.org/10.1785/0220150263

Bao, X., \& Eaton, D. W. (2016). Fault Activation by Hydraulic Fracturing in Western Canada. Science, 354, 1406-1409. https://doi.org/10.1126/science.aag2583

Barbaie Mahani, A., Kao, H., Atkinson, G. M., Assatourians, K., Addo, K., \& Liu, Y. (2019). Ground-Motion Characteristics of the 30 November 2018 Injection-Induced Earthquake Sequence in Northeast British Columbia, Canada. Seismological Research Letters, 90, 1457-1467. https://doi.org/10.1785/0220190040

Barbaie Mahani, A., Schultz, R., Kao, H., Walker, D., Johnson, J., \& Salas, C. (2017). Fluid Injection and Seismic Activity in the Northern Montney Play, British Columbia, Canada, with Special Reference to the 17 August 2015 Mw 4.6 Induced Earthquake. Bulle- 
tin of the Seismological Society of America, 107, 542-552.

https://doi.org/10.1785/0120160175

Barclay, J. E., Krause, F. F., Campbell, R. I., \& Utting, J. (1990). Dynamic Casting of a Graben Complex: Basin Infill and Differential Subsidence during the Permo-Carboniferous, Peace River Embayment, Western Canada. Bulletin of Canadian Petroleum Geology, 38A, 115-145. https://www.researchgate.net/publication/316619696

BCGOV (British Columbia Government) (2020a). Government of British Columbia, Petroleum and Natural Gas Tenure Sales.

https://www2.gov.bc.ca/gov/content/industry/natural-gas-oil/petroleum-natural-gas-te nure/sales-results-statistics

BCGOV (British Columbia Government) (2020b). Drilling and Production Regulation (Oil and Gas Activities Act).

https://www.bclaws.gov.bc.ca/civix/document/id/complete/statreg/282 2010\#section21.1

BCOGC (British Columbia Oil and Gas Commission) (2012a). Montney Format Play Atlas.

https://www.bcogc.ca/files/reports/Technical-Reports/montney-format-play-atlas-nebc .pdf

BCOGC (British Columbia Oil and Gas Commission) (2012b). Investigation of Observed Seismicity in the Horn River Basin.

https://www.bcogc.ca/files/reports/Technical-Reports/investigation20of20observed20se ismicity20in20the20horn20river20basinaug202012.pdf

BCOGC (British Columbia Oil and Gas Commission) (2014). Investigation of Observed Seismicity in the Montney.

https://www.bcogc.ca/files/reports/Technical-Reports/investigation-observed-seismicit y-montney-trend.pdf

BCOGC (British Columbia Oil and Gas Commission) (2018).

https://www.bcogc.ca/files/reports/Technical-Reports/Kiskatinaw-Seismic-Monitoringand-Mitigation-Area-KSMMA-Special-Project-Order-18-90-001-Amendment-1.pdf

BCOGC (British Columbia Oil and Gas Commission) (2020a). Complete Frac Focus Data [BCOGC-2643]. https://reports.bcogc.ca/ogc/f?p=200:2:1057249272671::NO

BCOGC (British Columbia Oil and Gas Commission) (2020b). Regional Fields. https://data-bcogc.opendata.arcgis.com/datasets/2e34e8d9065a46929a9dfdbf97ad3838_ 1

BCOGC (British Columbia Oil and Gas Commission) (2020c). Wells and Facility AreasPermitted.

https://data-bcogc.opendata.arcgis.com/datasets/3550539a554a426ba537223acf4642e9 1

BCOGC (British Columbia Oil and Gas Commission) (2021). BCOGC Webinar for Montney Researchers. https://www.bcogc.ca/search/?q=BCOGC\%20Webinar

Canada Energy Regulator (2020). Canadian Export Prices for Natural Gas and Natural Gas Liquids. https://apps.cer-rec.gc.ca/CommodityStatistics/Statistics.aspx

Dusseault, M., \& McLennan, J. (2011). Massive Multi-Stage Hydraulic Fracturing: Where Are We? 45th US Rock Mechanics/Geomechanics Symposium, San Francisco, 26-29 June 2011, 14.

http://tm.spbstu.ru/images/f/ff/Review Massive Multi-Stage Hydraulic Fracturing Where are We.pdf

Eaton, D. W., \& Igonin, N. (2018). What Controls the Maximum Magnitude of Injection-Induced Earthquakes? The Leading Edge, 37, 135-140.

https://doi.org/10.1190/tle37020135.1

Euzen, T., Moslow, T. F., Crombez, V., \& Rohais, S. (2018). Regional Stratigraphic Archi- 
tecture of the Spathian Deposits in Western Canada-Implications for the Montney Resource Play. Bulletin of Canadian Petroleum Geology, 66, 175-192.

Geoscience BC (2020). KSMMA and NPGMMA Locations. http://www.geosciencebc.com/projects/2019-008

Ghofrani, H., \& Atkinson, G. M. (2020). Activation Rate of Seismicity for Hydraulic Fracture Wells in the Western Canada Sedimentary Basin. Bulletin of the Seismological Society of America, 110, 2252-2271. https://doi.org/10.1785/0120200002

Ghofrani, H., \& Atkinson, G. M. (2021). Activation Rate of Seismicity for Hydraulic Fracture Wells in the Western Canada Sedimentary Basin-An Update. https://doi.org/10.1785/0120200002

Goebel, T. H., Weingarten, M., Chen, X., Haffener, J., \& Brodsky, E. (2017). The 2016 Mw5.1 Fairview, Oklahoma Earthquakes: Evidence for Long-Range Poroelastic Triggering at $>40 \mathrm{~km}$ from Fluid Disposal Wells. Earth and Planetary Science Letters, 472, 50-61. https://doi.org/10.1016/j.epsl.2017.05.011

Guglielmi, Y., Cappa, F., Avouac, J., Henry, P., \& Elsworth, D. (2015). Seismicity Triggered by Fluid Injection-Induced Aseismic Slip. Science, 348, 1224-1226. https://doi.org/10.1126/science.aab0476

Horner, R. B., Barclay, J. E., \& MacRae, J. M. (1994). Earthquakes and Hydrocarbon Production in the Fort St. John Area of Northeastern British Columbia. Canadian Journal of Exploration Geophysics, 30, 39-50.

https://www.researchgate.net/publication/283917337

Kao, H., Hyndman, R., Jiang, Y., Visser, R., Smith, B., Babaie Mahani, A., Leonard, L., Ghofrani, H. et al. (2018). Induced Seismicity in Western Canada Linked to Tectonic Strain Rate: Implications for Regional Seismic Hazard. Geophysical Research Letters, 45, 11,104-11,115. https://doi.org/10.1029/2018GL079288

Lei, X., Wang, Z., \& Su, J. (2019). The December 2018 ML 5.7 and January 2019 ML 5.3 Earthquakes in South Sichuan Basin Induced by Shale Gas Hydraulic Fracturing. Seismological Research Letters, 90, 1099-1110. https://doi.org/10.1785/0220190029

Lemko, M., \& Foster, S. (2016). Multivariate Statistical Analysis of Montney Completions: Taking Aim at Design Improvements. 2016 Unconventional Gas Technology Forum, Victoria, 4-5 April 2016, 37. https://www.canadiandiscovery.com/sites/default/files/ugtf 2016 mvstats april 5 fina l.pdf

McGarr, A. (2014). Maximum Magnitude Earthquakes Induced by Fluid Injection. Journal of Geophysical Research: Solid Earth, 119, 1008-1019. https://doi.org/10.1002/2013JB010597

Nikiforuk, A. (2018). Oil and Gas Commission Confirms Fracking Caused Earthquakes Felt by Hundreds. The Tyee, 31 December 2018. https://thetyee.ca/News/2018/12/31/Oil-Gas-Commission-Confirms-Earthquakes

NRCAN (Natural Resources Canada) (2020). National Earthquake Database. https://earthquakescanada.nrcan.gc.ca/stndon/NEDB-BNDS/bulletin-en.php

Parfitt, B. (2017). A Dam Big Problem: Regulatory Breakdown as Fracking Companies in $B C$ 's Northeast Build Dozens of Unauthorized Dams. Ottawa: Canadian Centre for Policy Alternatives.

https://www.policyalternatives.ca/publications/reports/dam-big-problem

QGIS (2020). https://qgis.org/en/site

Rogers, N. (2020). The Year Fracking Earthquakes Turned Deadly. Inside Science, February $21,2020$. 
https://www.insidescience.org/news/2019-year-fracking-earthquakes-turned-deadly

Schultz, R., Atkinson, G. M., Eaton, D. W., Yu, Y. J., \& Kao, H. (2018). Hydraulic Fracturing Completion Volume Is Associated with Induced Earthquake Productivity in the Duvernay Play. Science, 359, 304-308. https://doi.org/10.1126/science.aao0159

Schultz, R., Beroza, G., \& Ellsworth, W. (2021). A Risk-Based Approach for Managing Hydraulic Fracturing-Induced Seismicity. Science, 372, 504-507.

https://doi.org/10.1126/science.abg5451

Schultz, R., Beroza, G., Ellsworth, W., \& Baker, J. (2020b). Risk-Informed Recommendations for Managing Hydraulic Fracturing-Induced Seismicity via Traffic Light Protocols. Bulletin of the Seismological Society of America, 110, 2411-2422. https://doi.org/10.1785/0120200016

Schultz, R., Skoumal, R. J., Brudzinski, M. R., Eaton, D., Baptie, B., \& Ellsworth, W. (2020a). Hydraulic Fracturing-Induced Seismicity. Reviews of Geophysics, 58, e2019RG000695. https://doi.org/10.1029/2019RG000695

Schultz, R., Stern, V., \& Gu, Y. J. (2014). An Investigation of Seismicity Clustered near the Cordel Field, West Central Alberta, and Its Relation to a Nearby Disposal Well. Journal of Geophysical Research: Solid Earth, 119, 3410-3423. https://doi.org/10.1002/2013JB010836

Schultz, R., Stern, V., Novakovic, M., Atkinson, G. M., \& Gu, Y. (2015). Hydraulic Fracturing and the Crooked Lake Sequences: Insights Gleaned from Regional Seismic Networks. Geophysical Research Letters, 42, 2750-2758.

https://doi.org/10.1002/2015GL063455

Shell (2020). LNG Canada Project Profile.

https://www.shell.com/about-us/major-projects/lng-canada.html

Systat (2020). https://systatsoftware.com

Thompson, R. I. (1989). Stratigraphy, Tectonic Evolution and Structural Analysis of the Halfway River Map Area (94B), Northern Rocky Mountains, British Columbia (119 p.). Geological Survey of Canada, Memoir, Vol. 425. https://doi.org/10.4095/127002

van der Elst, N. J., Page, M. T., Weiser, D. A., Goebel, T. H. W., \& Hosseini, S. M. (2016). Induced Earthquake Magnitudes Are as Large as (Statistically) Expected. Journal of Geophysical Research: Solid Earth, 121, 4575-4590. https://doi.org/10.1002/2016JB012818

Visser, R., Kao, H., Smith, B., Goerzen, C., Kontou, B., Dokht, R. M. H., Hutchinson, J., Tan, F., \& Babaie Mahani, A. (2020). A Comprehensive Earthquake Catalogue for the Fort St. John-Dawson Creek Region, British Columbia, 2017-2018. Geological Survey of Canada, Open File 8718, 1. https://doi.org/10.4095/326015

Visser, R., Smith, B., Kao, H., Babaie Mahani, A., Hutchinson, J., \& McKay, J. E. (2017). A Comprehensive Earthquake Catalogue for Northeastern British Columbia and Western Alberta, 2014-2016. Geological Survey of Canada, Open File 8335, 1. https://doi.org/10.4095/306292

Weingarten, M., Ge, S., Godt, J. W., Bekins, B., \& Rubinstein, J. (2015). High-Rate Injection Is Associated with the Increase in US Mid-Continent Seismicity. Science, 348, 13361340. https://doi.org/10.1126/science.aab1345 